University of South Florida

DIGITAL COMMONS

@ UNIVERSITY OF SOUTH FLORIDA
Digital Commons @ University of

South Florida

8-1-2003

\title{
Analysis of the National Transit Database
}

CUTR

Follow this and additional works at: https://digitalcommons.usf.edu/cutr_nctr

\section{Recommended Citation}

"Analysis of the National Transit Database," National Center for Transit Research (NCTR) Report No. CUTR-NCTR-RR-2000-12, Center for Urban Transportation Research, University of South Florida, 2003. DOI: https://doi.org/10.5038/CUTR-NCTR-RR-2000-12

Available at: https://scholarcommons.usf.edu/cutr_nctr/34

This Technical Report is brought to you for free and open access by the National Center for Transit Research (NCTR) Archive (2000-2020) at Digital Commons @ University of South Florida. It has been accepted for inclusion in Research Reports by an authorized administrator of Digital Commons @ University of South Florida. For more information, please contact digitalcommons@usf.edu. 


\section{Final Report}

Report Number: NCTR 350-11

\section{Ridership Trends of New Start Rail Projects}

Project Staff:

Dr. Steve Polzin, Director Public Transit Research

Oliver Page, Graduate Research Assistant

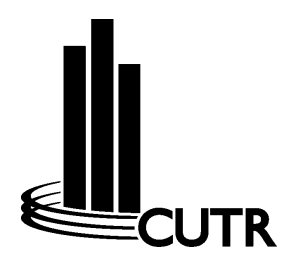

National Center for Transit Research Center for Urban Transportation Research

National BRT Institute

University of South Florida

4202 E. Fowler Avenue, CUT 100

Tampa, FL 33620-5375

(813) $974-3120$

August 2003 
The opinions, findings and conclusions expressed in this publication are those of the authors and not necessarily those of the U.S. Department of Transportation or the State of Florida Department of Transportation. 


\begin{tabular}{|c|c|c|c|}
\hline $\begin{array}{l}\text { 1. Report No. } \\
350-11\end{array}$ & 2. Government Accession No. & \multicolumn{2}{|c|}{ 3. Recipient's Catalog No. } \\
\hline \multirow{2}{*}{\multicolumn{2}{|c|}{$\begin{array}{l}\text { 4. Title and Subtitle } \\
\text { Ridership Trends of New Start Rail Projects }\end{array}$}} & \multicolumn{2}{|c|}{$\begin{array}{l}\text { 5. Report Date } \\
\text { August } 2003\end{array}$} \\
\hline & & \multicolumn{2}{|c|}{ 6. Performing Organization Code } \\
\hline \multicolumn{2}{|l|}{$\begin{array}{l}\text { 7. Author(s) } \\
\text { Polzin, Steve; Page, Oliver }\end{array}$} & \multicolumn{2}{|c|}{ 8. Performing Organization Report No. } \\
\hline \multirow{2}{*}{\multicolumn{2}{|c|}{$\begin{array}{l}\text { 9. Performing Organization Name and Address } \\
\text { National Center For Transit Research (NCTR) } \\
\text { University of South Florida CUT } 100 \\
4202 \text { East Fowler Avenue, Tampa, FL } 33620\end{array}$}} & \multicolumn{2}{|l|}{ 10. Work Unit No. } \\
\hline & & \multicolumn{2}{|c|}{$\begin{array}{l}\text { 11. Contract or Grant No. } \\
\text { DTRS98-G-0032 }\end{array}$} \\
\hline \multirow{2}{*}{\multicolumn{2}{|c|}{$\begin{array}{l}\text { 12. Sponsoring Agency Name and Address } \\
\text { Office of Research and Special Programs } \\
\text { U.S. Department of Transportation } \\
\text { Washington, DC } 20590\end{array}$}} & \multicolumn{2}{|c|}{ 13. Type of Report and Period Covered } \\
\hline & & \multicolumn{2}{|c|}{ 14. Sponsoring Agency Code } \\
\hline \multicolumn{4}{|c|}{$\begin{array}{l}\text { 15. Supplementary Notes } \\
\text { Supported by a grant from the U.S. Department of Transportation. }\end{array}$} \\
\hline \multicolumn{4}{|c|}{$\begin{array}{l}\text { 16. Abstract } \\
\text { This research reports on the ridership trends of new start Light Rail Transit (LRT) projects implemented in } \\
\text { the last two decades. These systems are colloquially referred to as "new start" systems. The purpose of } \\
\text { the research presented here is to look at the process of maturation of these systems in terms of ridership } \\
\text { trends. Each system's ridership is examined, and system extent in terms of route miles and service miles } \\
\text { also is examined. The research attempts to discern the impact of service expansion associated with the } \\
\text { system synergies that might result from increased accessibility. Performance is evaluated by reviewing } \\
\text { ridership changes as LRT systems grow and comparing them with changes in service supply. }\end{array}$} \\
\hline \multicolumn{4}{|c|}{$\begin{array}{l}\text { This review of the National Transit Database data (NTD) indicates that ridership trends for new start LRT } \\
\text { projects matured relatively quickly, with subsequent growth driven by system extent and service levels. } \\
\text { The initial rapid maturation is partially attributable to the high levels of attention light rail lines receive when } \\
\text { they are under development and implemented, as well as the inherent physical presence that LRT provides } \\
\text { for transit. It is interesting to note that the LRT systems, even the more mature systems, are a modest } \\
\text { share of the urban area's total transit service, with the most successful systems providing approximately } 30 \\
\text { percent of total regional transit trips. LRT investments may be very important to a community by stimulating } \\
\text { attention and investment in public transit. LRT implementation has helped several communities expand } \\
\text { public transit use; however, it has not resulted in dramatic changes in the role that public transit plays in } \\
\text { regional mobility in the respective communities. While LRT is playing an important role in expanding } \\
\text { opportunities for transit use, even LRT system development is a lengthy process with a mixed record in } \\
\text { terms of providing substantial growth in transit ridership. }\end{array}$} \\
\hline $\begin{array}{l}\text { 17. Key Words } \\
\text { Light Rail, Ridership Trends, New } \\
\text { Starts }\end{array}$ & $\begin{array}{l}\text { 18. Distribution Statement } \\
\text { Available to the public } \\
\text { (NTIS), } 5285 \text { Port Ro } \\
\text { through the NCTR we }\end{array}$ & $\begin{array}{l}\text { lational Tech } \\
\text { ngfield, VA 2? } \\
\text { Nww.nctr.usf. }\end{array}$ & $\begin{array}{l}\text { nation Service } \\
05-6000 \text { and }\end{array}$ \\
\hline $\begin{array}{l}\text { 19. Security Classif. (of this report) } \\
\text { Unclassified }\end{array}$ & $\begin{array}{l}\text { 20. Security Classif. (of this page) } \\
\text { Unclassified }\end{array}$ & $\begin{array}{l}\text { 21. No. of pages } \\
42\end{array}$ & 22. Price \\
\hline
\end{tabular}




\section{Table of Contents}

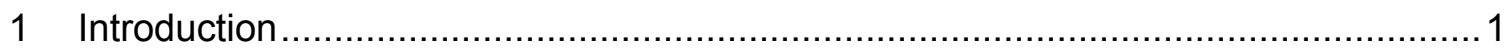

2 Llght Rail Systems an overview ............................................................... 2

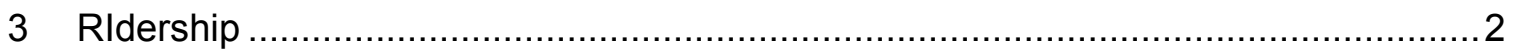

3.1 Light Rail Transit Ridership Statistics .................................................... 5

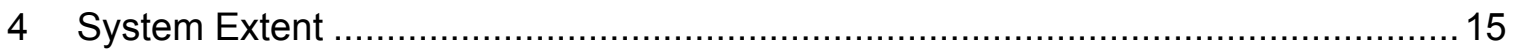

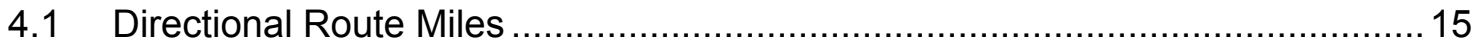

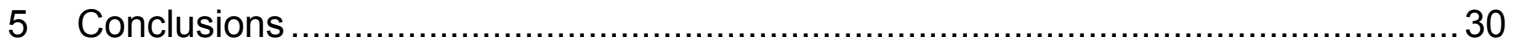

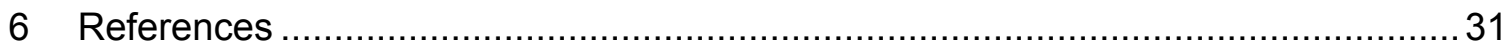

Appendix A

Acknowledgements 


\section{List of Figures}

Figure 1 New Start Light Rail Transit Year-over-Year Ridership Trends

Figure $2 \quad$ New Start Light Rail Transit versus All LRT Year-over-Year Ridership Trends ............................................................... 7

Figure $3 \quad$ Light Rail Transit Rolling 3 Year Average Ridership ............................ 10

Figure 4.1 Transit Ridership Trends in Portland OR $\quad$.......................................... 11

Figure 4.2 Transit Ridership Trends in Buffalo NY ......................................... 11

Figure $4.3 \quad$ Transit Ridership Trends in Dallas TX ........................................... 12

Figure 4.4 Transit Ridership Trends in St. Louis MO........................................ 12

Figure 4.5 Transit Ridership Trends in Salt Lake City UT .................................. 13

Figure 4.6 Transit Ridership Trends in Denver CO .......................................... 13

Figure $4.7 \quad$ Transit Ridership Trends in San Jose CA ....................................... 14

Figure 4.8 Transit Ridership Trends in Sacramento CA ..................................... 14

Figure $5 \quad$ Light Rail Transit Directional Route Miles......................................... 16

Figure $6 \quad$ New Start Light Rail Transit Total Directional Route Miles and Stations ................................................................ 17

Figure $7 \quad$ Light Rail Transit Ridership per Directional Route Mile ............................ 18

Figure $8 \quad$ Change in Light Rail Transit Directional Route Mile Versus Change in Ridership .............................................................. 22

Figure $9 \quad$ New Start Light Rail Transit Annual Average Trip Length ........................ 24

Figure $10 \quad$ Unlinked New Start LRT Trips per Capita ........................................ 25

Figure $11 \quad$ New Start Light Rail Transit Annual Ridership Percent of System Wide Ridership .............................................................. 26

Figure 12 New Start Light Rail Transit Passenger Miles Served per

Directional Route Mile........................................................ 28

Figure 13 Passenger Miles per Passenger Car Revenue Miles Of Service ............... 29 


\section{List of Tables}

Table 1 LRT Systems as of December 2001 (Listed According to Service

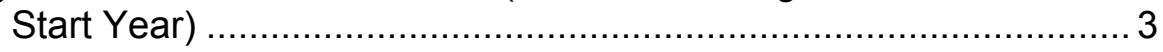

Table 2 LRT Compound Rate of Change (Service Start Year to 2001) ................. 8

Table 3 Percentage Change in Directional Route Mileage and Corresponding Change in Ridership..................................... 21 


\section{INTRODUCTION}

During the past two decades, several urban areas have invested in Light Rail Transit systems (LRT) with the expectation that these systems would attract substantial ridership and hence, contribute to meeting the mobility needs of the community. The debate continues as to what extent new transit developments can impact positively on the balance between private vehicles versus transit trip-making levels. Available statistics indicate that, during the latter half of the 1990's, overall transit ridership grew by 21 percent, with the largest increase in the growth attributed to rail passengers (Pucher, 2002). During this same period, a number of LRT projects were implemented, building on earlier new start LRT developments since 1980. Both National Transit Data (NTD) and National Household Travel Survey (NHTS) data indicate that a growing share of all transit trips are on rail systems including light rail, commuter rail and heavy rail (Polzin, 2003). Analysis of the ridership trends of these new start LRT systems can help to provide a richer understanding of the role that LRT systems are having. In addition, by looking at how ridership levels change as systems mature, it may be possible to shed some light on the impacts LRT systems will have as they reach maturity.

This analysis attempts to shed light on the extent to which systems show maturation in terms of ridership growth over the near term as awareness of the system grows, and over the longer term as might be a result of changing demographics, changes in mode choice of travelers, or increased transit accessibility as the overall transit system expands. The research attempts to discern the impact of service expansion associated with the system synergies that might result from increased accessibility, through the review of the relative changes in ridership and service supply.

This paper analyzes LRT systems constructed during the period 1980 to 2001 . These systems are colloquially referred to as "new start" systems. Exploration of transit data as contained in the NTD is the primary method of analysis and was supplemented by literature searches and exchanges of information with transportation experts in the transit data field. Due to the available data, the analysis is restricted to reviewing LRT ridership and region wide bus and total ridership. These data sources do not allow corridor specific analyses of ridership changes and system impacts. One would expect corridor level impacts to be more significant due to the more limited geography. 


\section{LIGHT RAIL SYSTEMS AN OVERVIEW}

LRT can be defined as "a metropolitan electric railway system characterized by its ability to operate single cars or short trains along exclusive rights-of-way at ground level, on aerial structures, in subways or, occasionally, in streets, and to board and discharge passengers at track or car-floor level" (Transportation Research Board, 1989). An alternative and possibly later definition, illustrating how LRTs have increasingly shared the road space with other road users, defines LRT as "rail cars with motive capability, usually driven by electric power taken from overhead lines, configured for passenger traffic and usually operating on non-exclusive rights of way" (APTA, 2002). LRT as a term has primarily been used to define light rail systems constructed after 1970; before that year, the terms streetcar, trolley, or tram often were used.

According to the 2001 NTD, there were 24 LRT systems in operation in the U.S. Of these 24 systems, 17 (or 70 percent) were "new start" projects, i.e. constructed during or after 1980. Key characteristics of these 24 systems are presented in Table 1. The last column in Table 1 indicates the first year of NTD availability with respect to LRT systems being studied. Differences in the actual start year of the LRT system, when compared to the first year of data supplied may be due to calendar versus fiscal year accounting policies of the respective systems.

Table 1 also includes the 17 new start LRT systems. The LRT systems of Seattle, Memphis and Kenosha (Wisconsin), though new start projects, are also heritage/vintage "trolley" systems that function differently from true LRT systems. Therefore, these three LRT systems have not been included in the analysis that follows. An additional note on NTD and the analysis performed on this data is provided in Appendix $A$.

\section{RIDERSHIP}

Ultimately, the fundamental benefit of a transit investment is dramatically dependent on its role in providing mobility. Energy savings, air quality contributions, congestion relief, offsetting roadway infrastructure needs, etc., all require the transit services to be utilized by travelers for these benefits to be captured. While the economic impact of construction will occur regardless of the system's subsequent success, even the land use influencing power of LRTs ultimately will be dependent on the system servicing a meaningful role in providing mobility. Thus, understanding the ridership response to LRT implementation is critical to understanding the contributions of the investments. The fundamental premise in LRT development is that the 


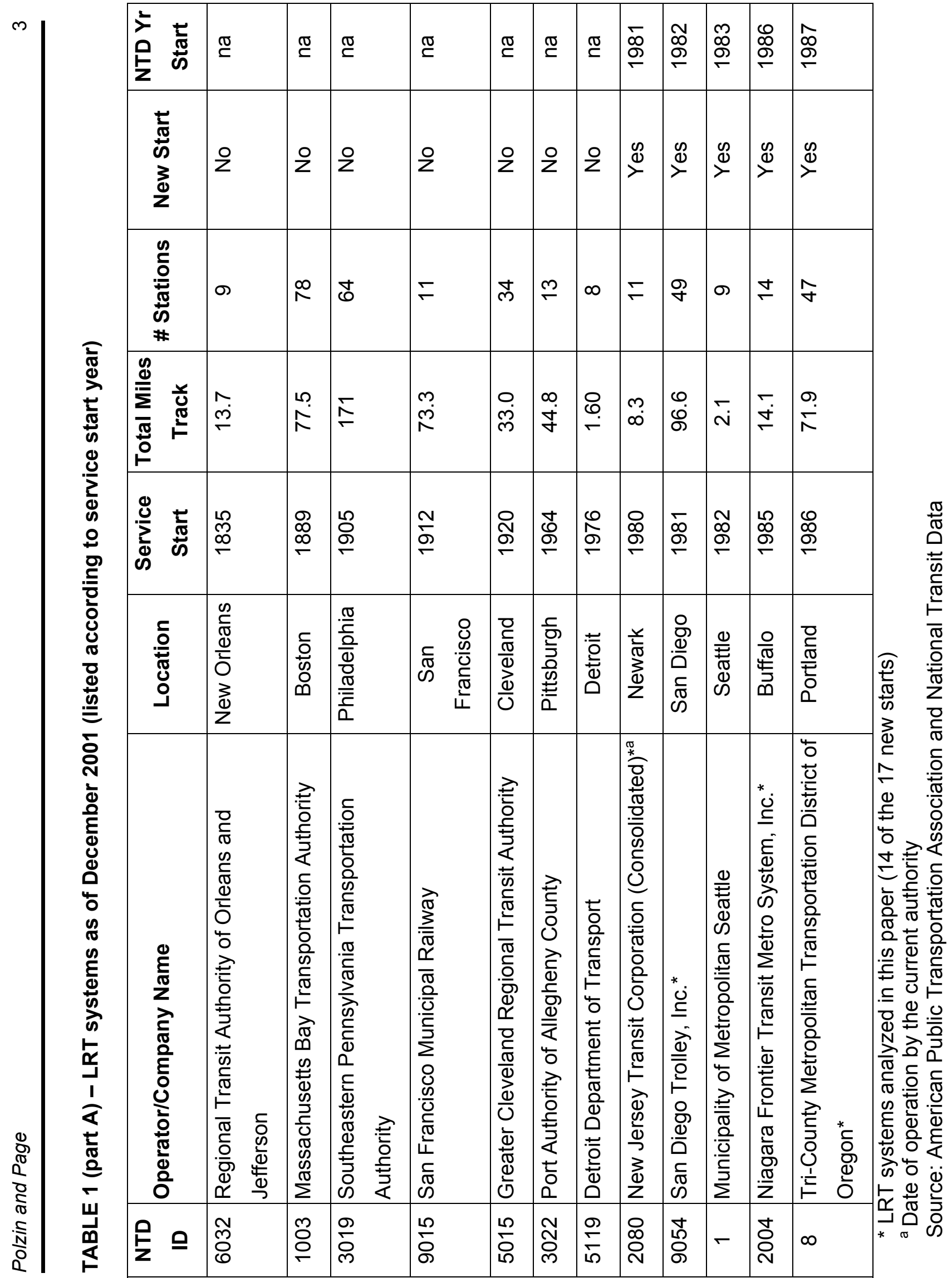




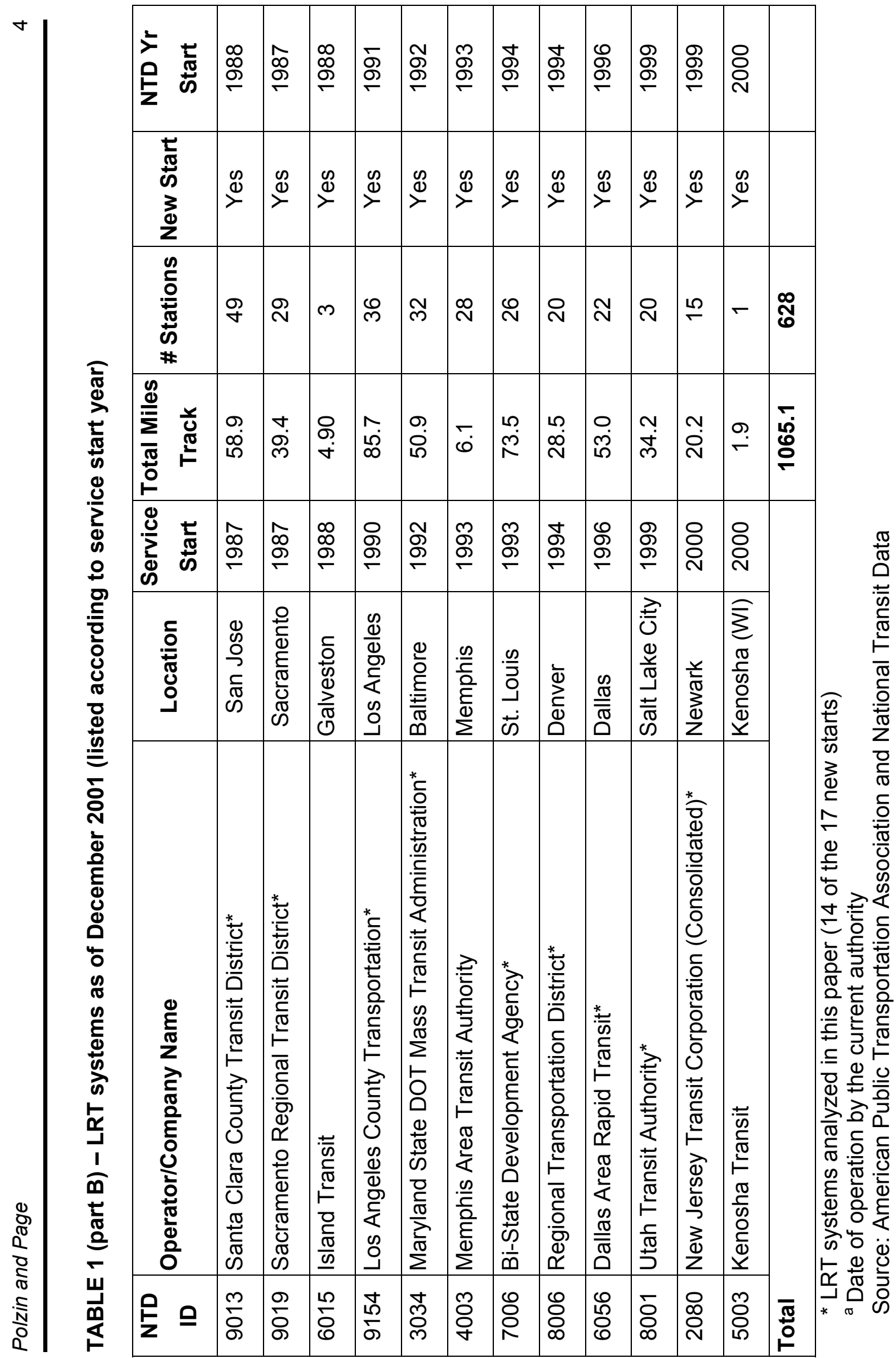


service will play a meaningful role in transporting passengers; therefore, they are typically developed in areas with proven transit market conditions. Similarly, one anticipates additional land development near the LRT investments creating additional demand and, as the overall rail system and accompanying bus system expands in the community over time, one anticipates additional ridership as the geographic coverage and temporal availability of transit improves.

To what extent do the ridership data for new start LRT systems confirm these predictions of increased transit usage? The analysis presented in the following discussion seeks to shed light on this question.

\subsection{Light Rail Transit Ridership Statistics}

Figure 1 presents ridership statistics for 13 LRT systems in the U.S. These ridership statistics have been standardized across systems by showing the ridership plotted versus the number of years each system has been in service. It is evident from Figure 1 that three LRT systems (all in U.S. west coast states) approximated or surpassed 25 million/year ridership levels. These 3 LRT systems, which operate in Los Angeles, San Diego and Portland, are distinctly noticeable in that only two of the other LRT systems (St. Louis and Buffalo) have experienced annual ridership levels in excess of 10 million/year during any 12-month period of their operational lifetime.

Figure 2 presents the overall ridership trends of all new LRT systems (both the 17 new start and those in service pre-1980). Since the mid 1980's, total LRT ridership has grown steadily, spiking in 1994 at 284 million trips and reaching 336 million trips in 2001 . New start LRT ridership has had a continuous upward trend in ridership since 1980. This may be partly due to any dips or stabilization of ridership levels in a system being counterbalanced by the opening of another system or extension elsewhere. The 164 million riders who used new start LRT systems in 2001, represented approximately 50 percent of all unlinked trips made on all LRT systems in the U.S. When total LRT ridership is compared to total transit ridership for the year 2001, it comprises 3.5 percent of all trips made (total transit ridership approximated 9.65 billion unlinked trips as per APTA data). On average, between the years 1990 to 2001, the new start program has produced 254,000 trips annually per track mile and 454,000 trips annually per new station. 


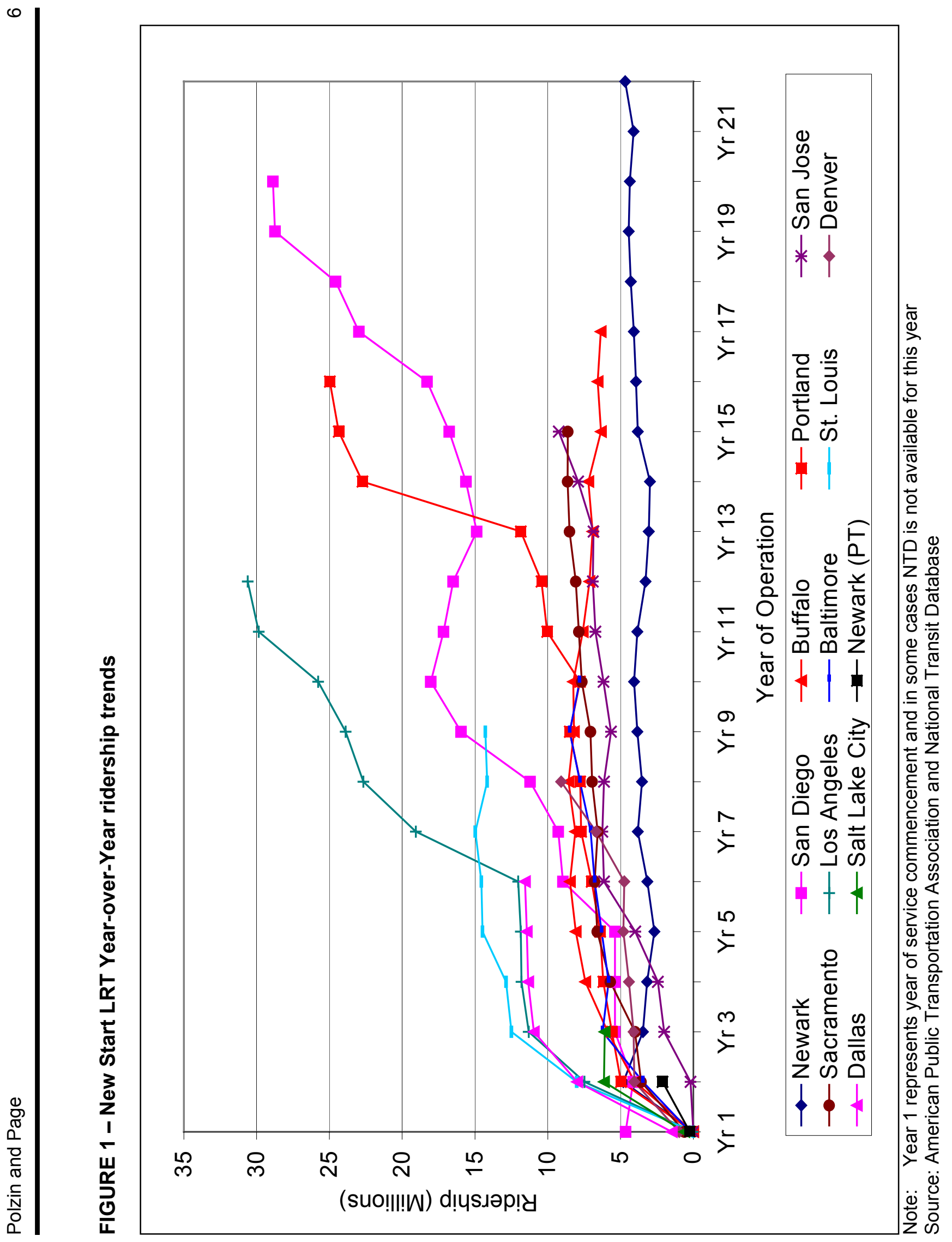




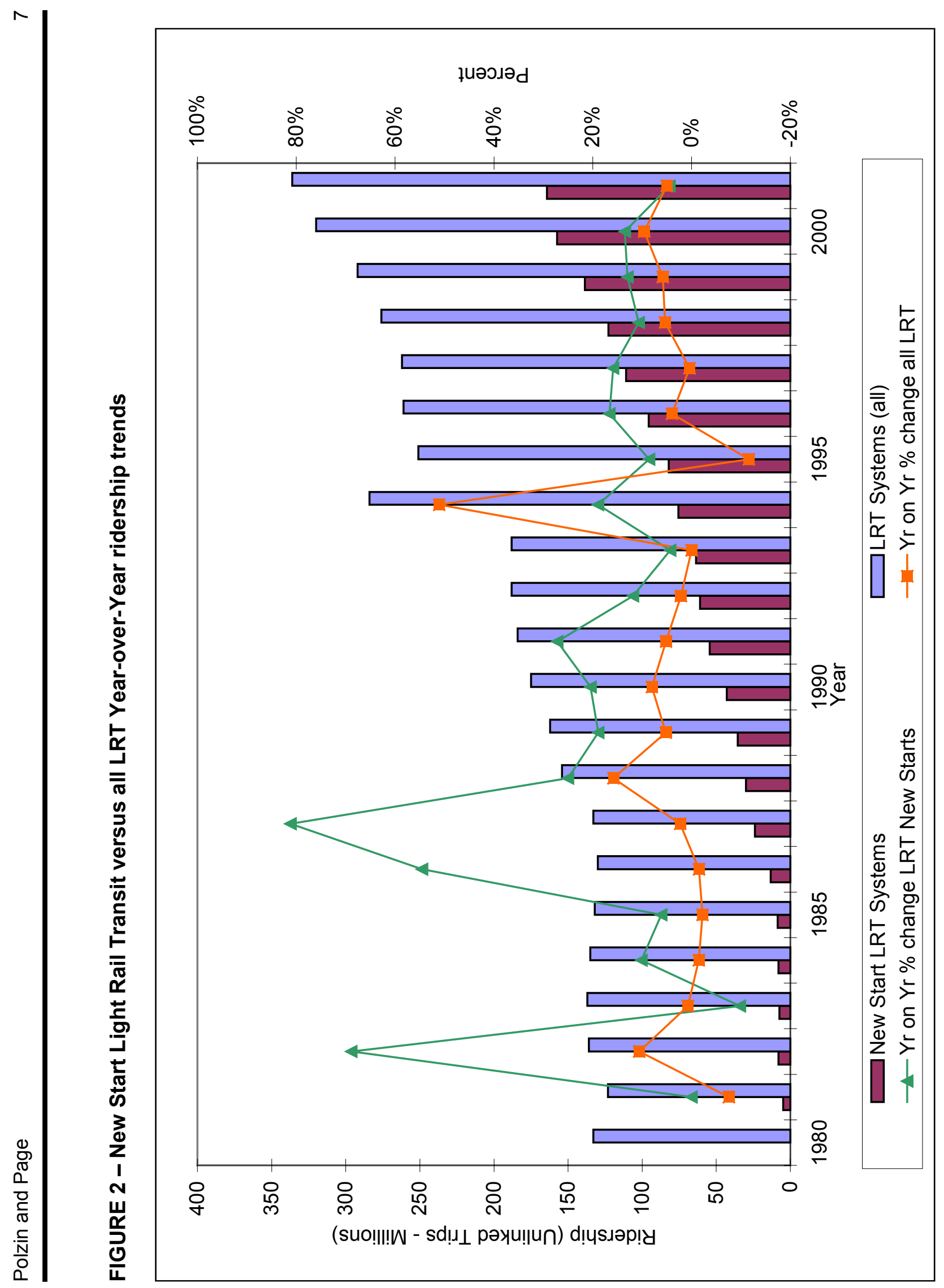

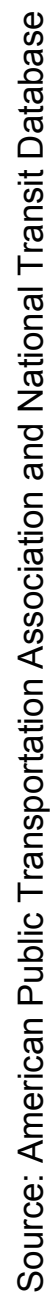


Figure 2 presents year-over-year growth rates for both new start and mature systems. The pronounced peaks and troughs in growth rates experienced during the 1980's and mid 1990's seem to have stabilized somewhat during the late 1990's. In particular the peak in LRT

TABLE 2 - LRT Compound rate of change (service start year to 2001)

\begin{tabular}{|c|c|c|c|c|c|}
\hline Operator/Company Name & $\begin{array}{l}\text { Service } \\
\text { Start }\end{array}$ & $\begin{array}{l}\text { Data } \\
\text { Year } \\
\text { Start }\end{array}$ & $\begin{array}{l}\text { Number } \\
\text { of Years }\end{array}$ & $\begin{array}{l}\text { Annual Growth } \\
\text { Rate (Data Year } \\
\text { Start } 12 / 31 \text { to } \\
12 / 31 / 2001)\end{array}$ & Rank \\
\hline $\begin{array}{l}\text { Regional Transportation District } \\
\text { (Denver) }\end{array}$ & 1994 & 1995 & 6 & $14.4 \%$ & 1 \\
\hline Santa Clara County Transit District & 1987 & 1989 & 12 & $13.6 \%$ & 2 \\
\hline $\begin{array}{l}\text { Tri-County Metropolitan } \\
\text { Transportation District of Oregon } \\
\text { (Portland) }\end{array}$ & 1986 & 1988 & 13 & $12.2 \%$ & 3 \\
\hline Los Angeles County Transportation & 1990 & 1992 & 9 & $11.7 \%$ & 4 \\
\hline San Diego Trolley, Inc. & 1982 & 1983 & 18 & $11.4 \%$ & 5 \\
\hline $\begin{array}{l}\text { Maryland State DOT Mass Transit } \\
\text { Administration (Baltimore) }\end{array}$ & 1992 & 1993 & 8 & $10.7 \%$ & 6 \\
\hline Dallas Area Rapid Transit & 1996 & 1997 & 4 & $9.8 \%$ & 7 \\
\hline Sacramento Regional Transit District & 1987 & 1988 & 13 & $7.0 \%$ & 8 \\
\hline $\begin{array}{l}\text { Bi-State Development Agency } \\
\text { (St. Louis) }\end{array}$ & 1993 & 1995 & 6 & $2.3 \%$ & 9 \\
\hline $\begin{array}{l}\text { New Jersey Transit Corporation } \\
\text { (Consolidated) (Newark) }\end{array}$ & 1980 & 1982 & 19 & $1.6 \%$ & 10 \\
\hline $\begin{array}{l}\text { Niagara Frontier Transit Metro } \\
\text { System, Inc. (Buffalo) }\end{array}$ & 1985 & 1987 & 14 & $0.6 \%$ & 11 \\
\hline Utah Transit Authority & 1999 & 2000 & 1 & $-0.8 \%$ & 12 \\
\hline
\end{tabular}

Note: Data start year disregards NTD first year data for each respective system. Part-year operations, novelty attraction, aggressive marketing efforts and other ridership initiatives in the introductory years of a new LRT service may produce misleading first year ridership levels.

ridership in 1994 is partly attributed to 4 new start LRT systems commencing operations within the previous 4 years as well as the Federal Transit Administration's (FTA) reclassification of 
Boston's Green line from Heavy Rail (HR) to LRT in 1984. Table 2 presents compound growth rates for the LRT systems from service commencement to the year 2001.

The data presented in Table 2 illustrate the challenge of correlating growth rates to operational length of time (i.e., growth rates decline as operational time increases) as an indication of system maturity. This observation is alluded to in the data, in that there is an equal dispersion of "older" (i.e., systems in operation $>10$ years) and "younger" (i.e., systems in operation $<10$ years) new start LRT systems, in the top 6 and bottom 6 rank positions, respectively. The high compound growth rates as experienced by LRT systems in Denver, San Jose and Portland, may be due partly to the continued ability to attract riders, manifested through recent network expansions. All top three systems in Table 2 have extended their LRT networks within the last 4 years, positively impacting their total ridership levels.

Figure 3 presents the rolling three-year average ridership levels for 11 LRT systems. Each of these 11 systems shows positive growth trends through the first four years of operation (the exception being Newark). Further analysis of Figure 3 indicates that of the 6 new start LRT systems that have been in operation for 10 years or more, operational year 7 generally marks the point at which one or more systems experienced their first decrease in ridership growth. Nevertheless, it would be premature to conclude that after operational year 7 new start LRT ridership growth should stabilize.

As an indication of systemwide ridership levels before and after new start LRT introduction, Figures 4.1 to 4.8 present data for 8 selected transit systems. These graphics give an indication of the significance of the LRT system as part of the overall public transportation system, through sustaining or increasing overall transit ridership in each of the cities respectively. 


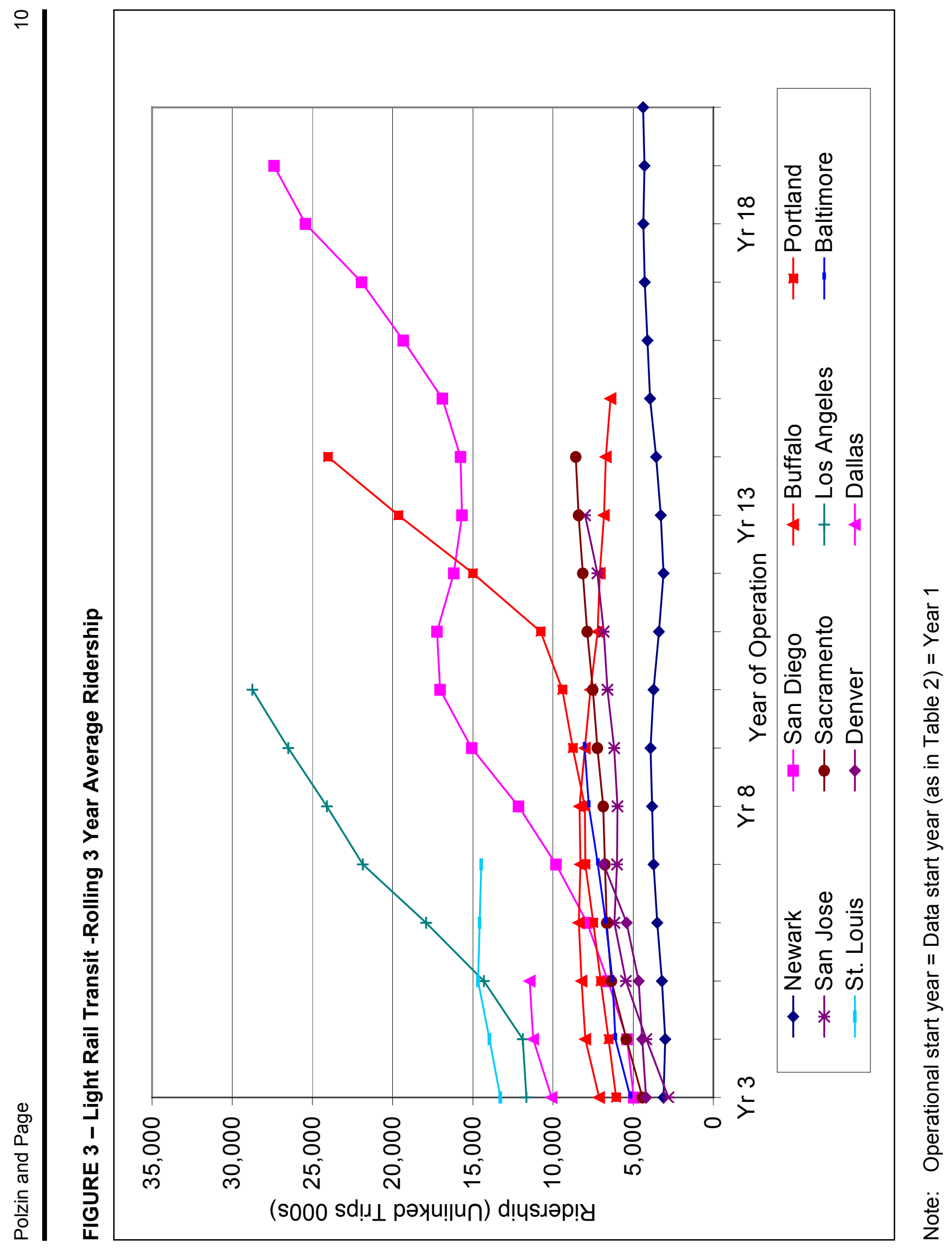


FIGURE 4.1: Transit Ridership Trends in Portland

Portland OR

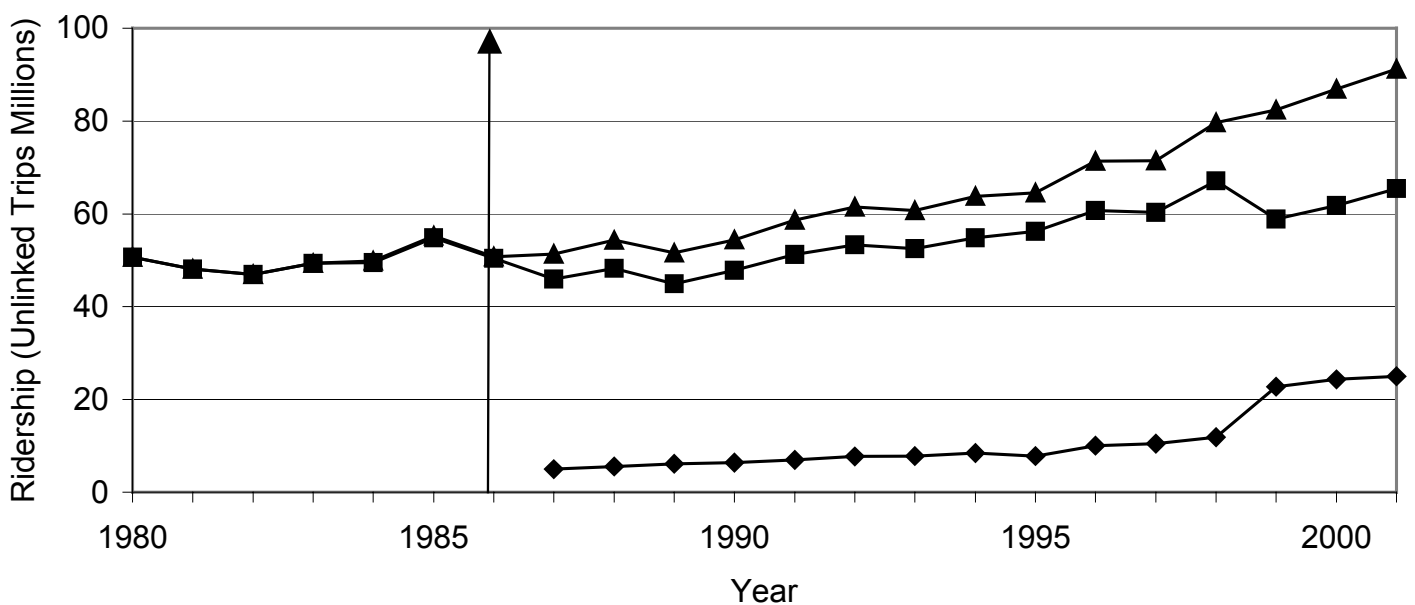

Note: Ridership in Millions; Up arrow represents year of introduction of LRT Key $=$ - Light Rail - Metro Bus $\Delta$ System wide Source: National Transit Database

FIGURE 4.2: Transit Ridership Trends In Buffalo

Buffalo NY

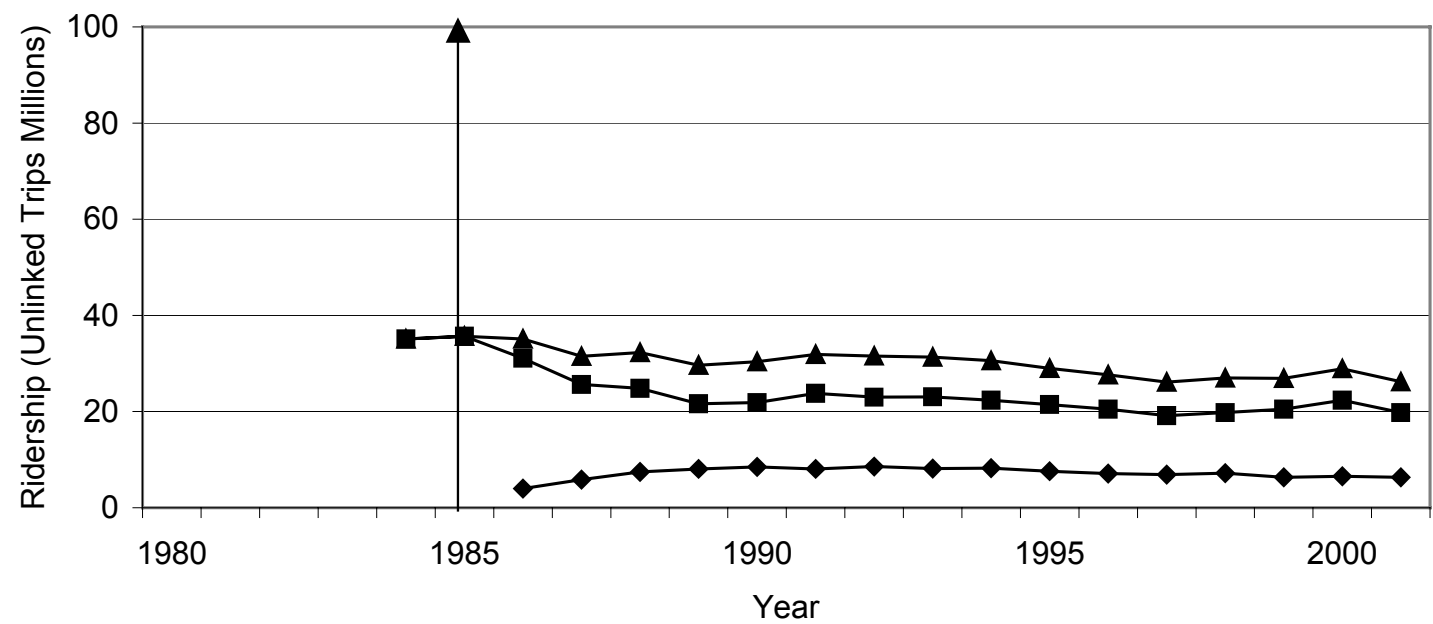

Note: Ridership in Millions; Up arrow represents year of introduction of LRT Key $=$ • Light Rail - Metro Bus $\Delta$ System wide Source: National Transit Database 
FIGURE 4.3: Transit Ridership Trends In Dallas

Dallas TX

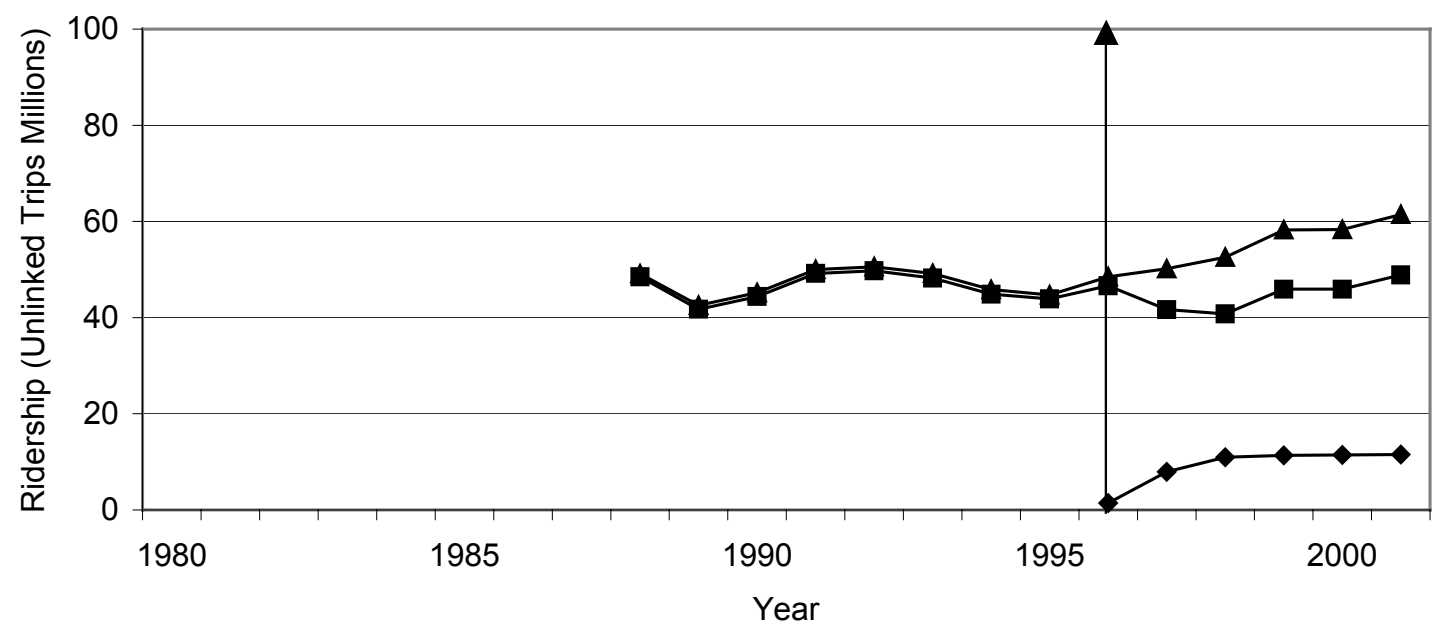

Note: Ridership in Millions; Up arrow represents year of introduction of LRT Key $=$ - Light Rail a Metro Bus $\boldsymbol{\Delta}$ System wide Source: National Transit Database

FIGURE 4.4: Transit Ridership Trends In St. Louis

St. Louis MO

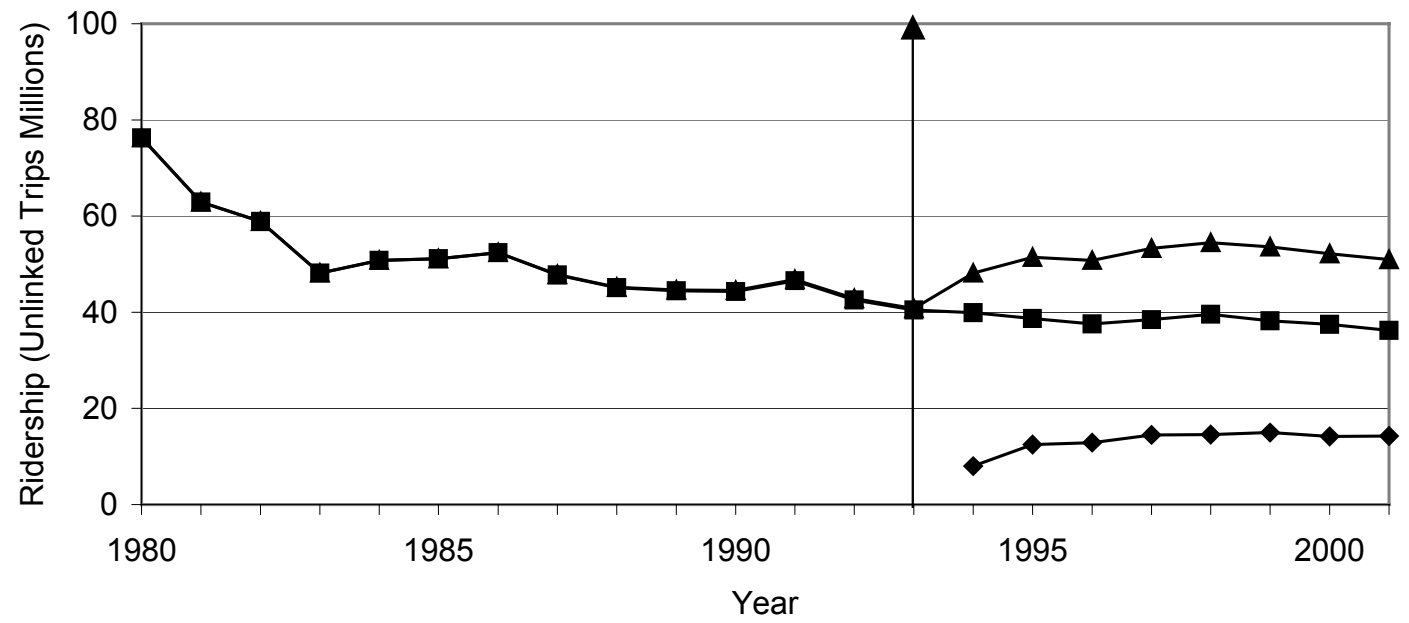

Note: Ridership in Millions; Up arrow represents year of introduction of LRT Key $=$ - Light Rail - Metro Bus $\Delta$ System wide Source: National Transit Database 
FIGURE 4.5: Transit Ridership Trends In Salt Lake City

Salt Lake City UT

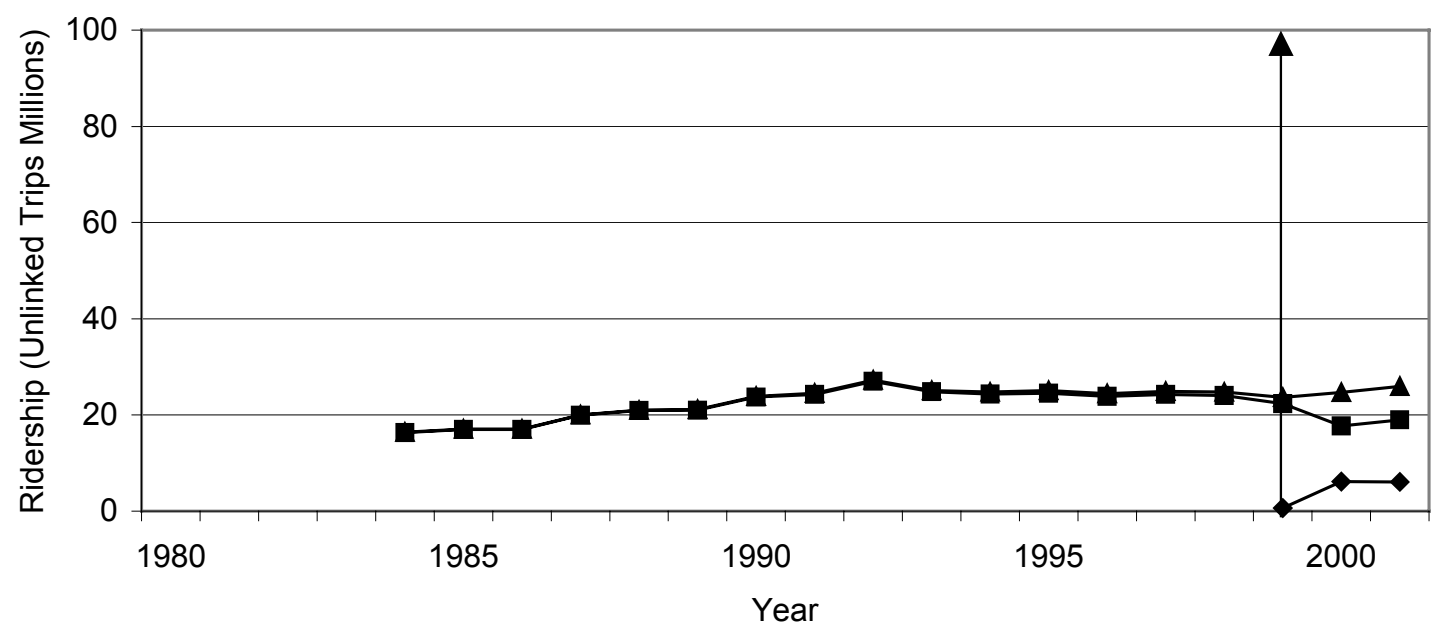

Note: Ridership in Millions; Up arrow represents year of introduction of LRT Key $=$ - Light Rail - Metro Bus $\boldsymbol{\Delta}$ System wide

Source: National Transit Database

FIGURE 4.5: Transit Ridership Trends In Denver

Denver CO

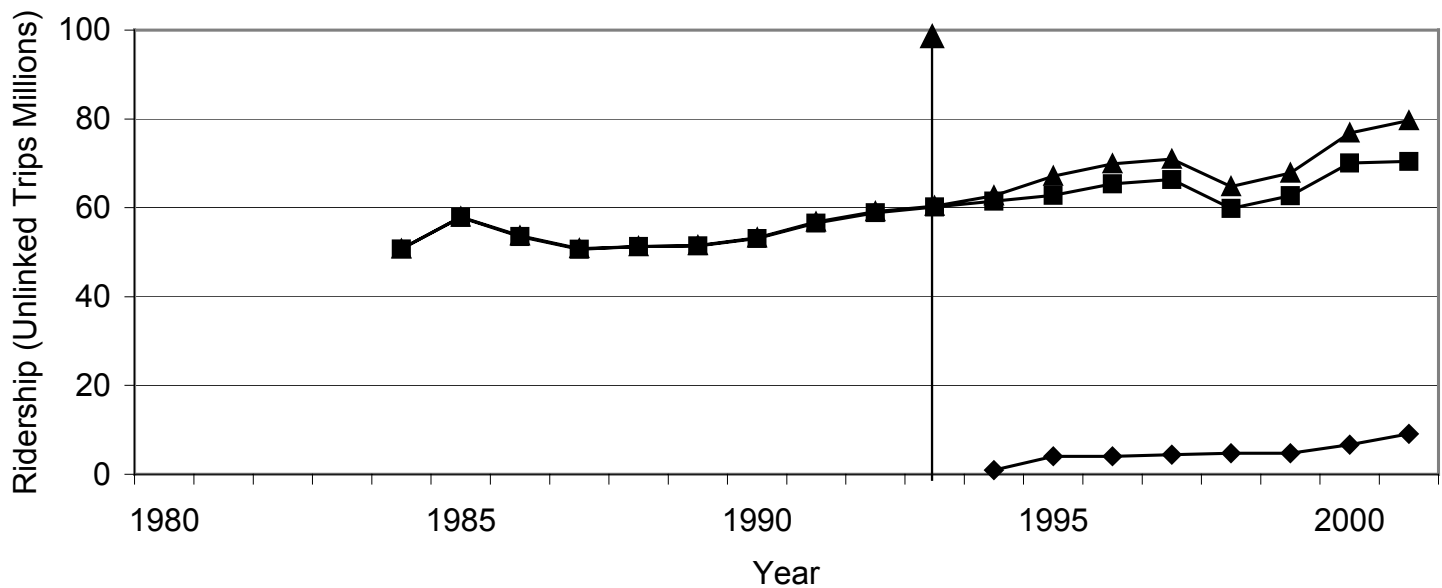

Note: Ridership in Millions; Up arrow represents year of introduction of LRT Key $=$ - Light Rail . Metro Bus $\Delta$ System wide Source: National Transit Database 
FIGURE 4.7: Transit Ridership Trends In Salt Lake City

San Jose CA

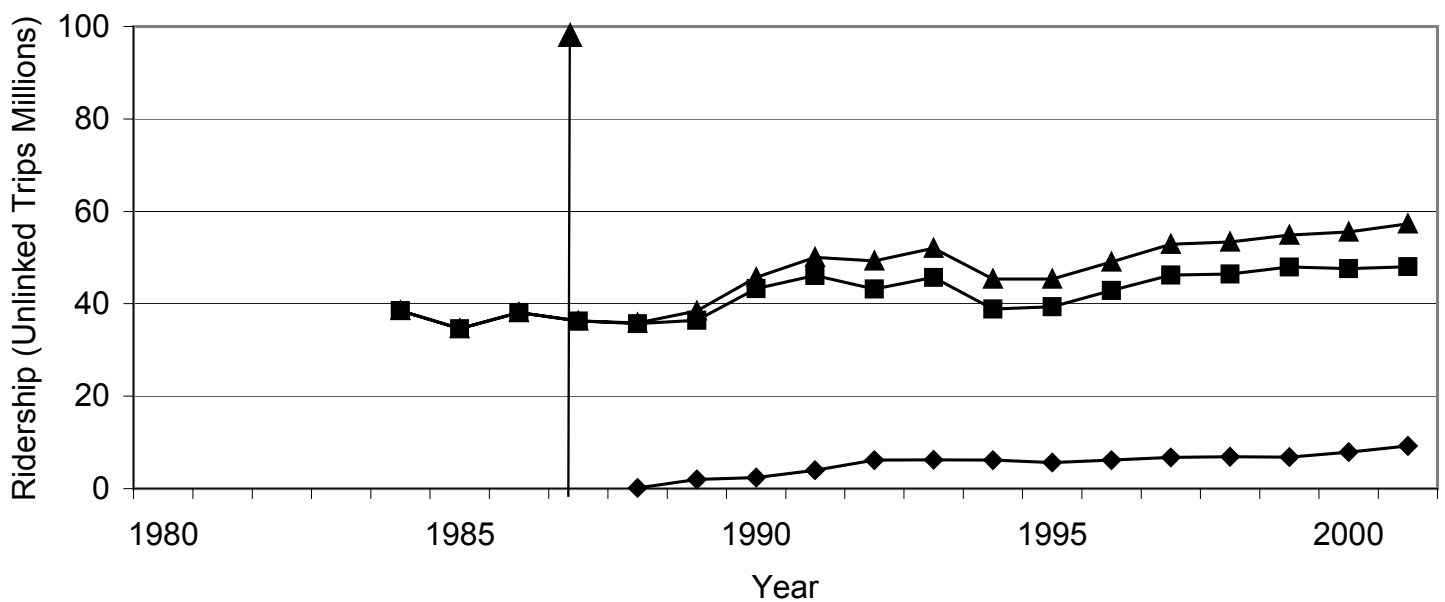

Note: Ridership in Millions; Up arrow represents year of introduction of LRT Key $=$ Light Rail - Metro Bus $\Delta$ System wide Source: National Transit Database

FIGURE 4.7: Transit Ridership Trends In Sacramento Sacramento CA

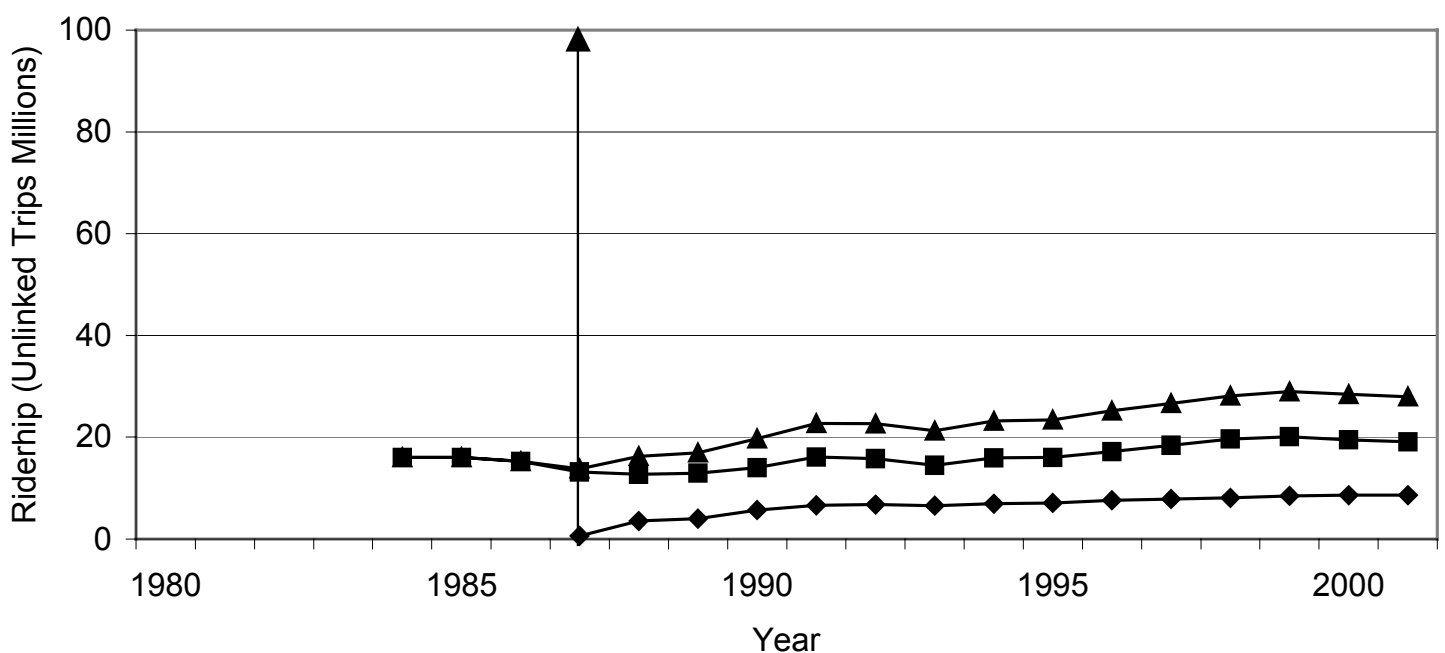

Note: Ridership in Millions; Up arrow represents year of introduction of LRT Key $=$ Light Rail - Metro Bus $\boldsymbol{\Delta}$ System wide Source: National Transit Database 


\section{SYSTEM EXTENT}

In this section LRT system extent will be looked at in terms of route miles and service miles. Obviously the extent of route and service miles will affect ridership.

\subsection{Directional Route Miles}

Figure 5 illustrates directional route miles for 15 new start LRT systems. The second half of the 1990's saw a significant expansion of many LRT systems, over that of the first half (9 new start LRT systems expanded during the period 1995 - 2000, versus 3 during the period 1990 - 1994). This expansion during the latter half of the 1990's coincided with the dispersion of ISTEA 21 funds, which, in turn, stimulated significant transit infrastructure enhancements and contributed to the subsequent increases in transit ridership in the U.S. At the end of 1990, new start LRT directional route miles approximated 146, with 107 stations (i.e., for LRT systems introduced during and post 1980); this increased to 299 miles with 227 stations at the end of 1995 (105 percent and 112 percent increases, respectively) and to 616 miles and 370 stations in 2001 (106 percent and 63 percent increases, respectively, from 1995). These changes are presented in Figure 6.

Passengers per directional route mile is used as a measure of the intensiveness of the use of a transit system. Thus, maturation of such systems may be evidenced from a tapering-off of total ridership levels per directional route mile. Theoretically, from new start LRT service inception, ridership per directional route mile increases to a certain level as awareness of the system grows; thus, subsequent growth should be at a rate that reflects the extent of population growth in the market area and changes in mode share. Even for fully-developed areas that are not growing, this might mean some relocation of population that needs or wants to use the LRT system who choose locations in proximity to the system over time as home and employment relocation opportunities are presented. Figure 7 illustrates intensity of ridership use of new start LRT riders per directional route mile. 


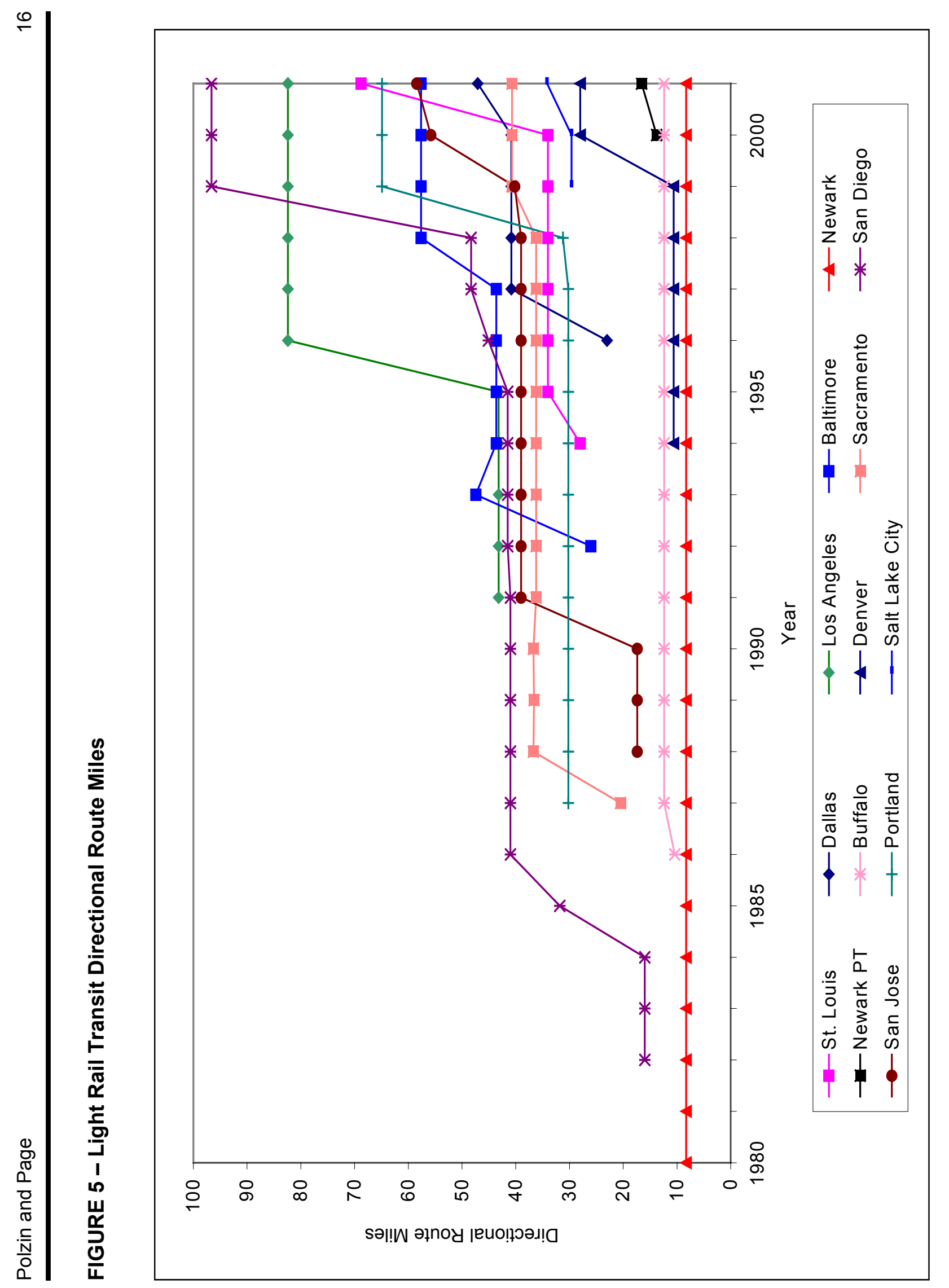

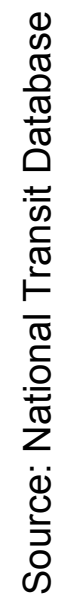




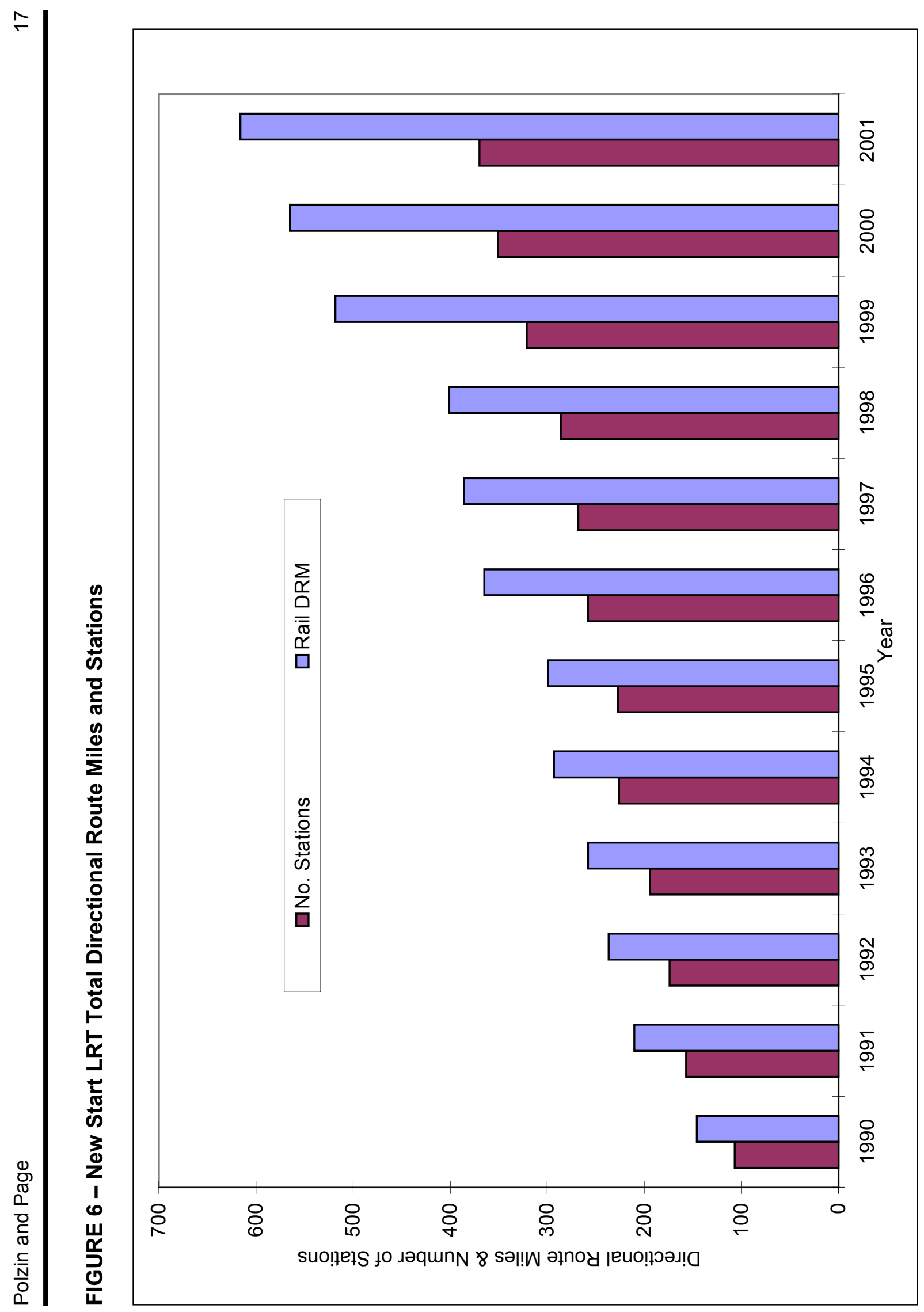




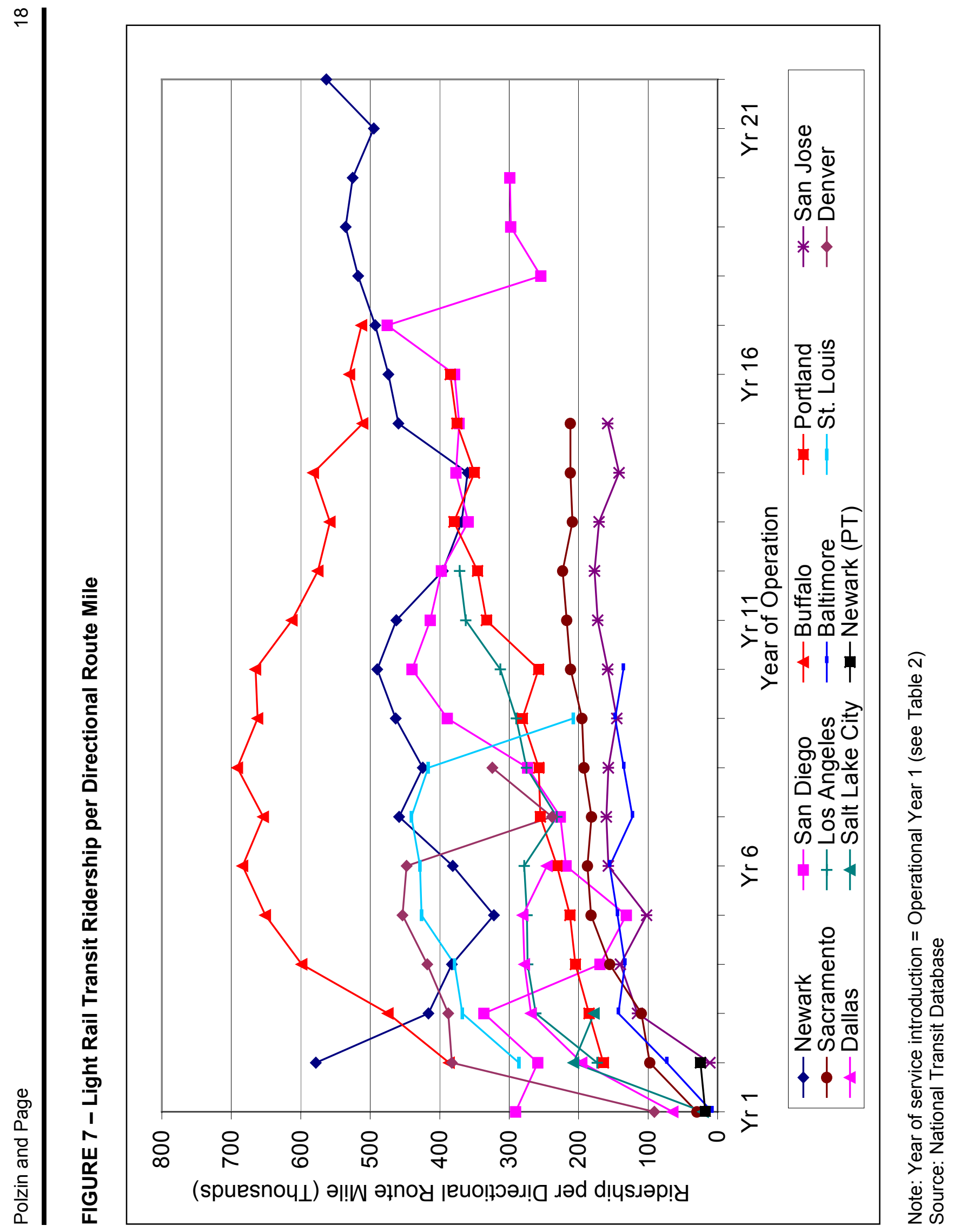


In Figure 7 it is evident that Niagara Frontier Transit Metro system (Buffalo) has had consistently high ridership levels per directional route mile from its early years of operation when compared to the other LRT systems. This is, no doubt, attributable to its short length and downtown focus. Sharp changes (either upward or downwards) in ridership per directional route are often due to changes in the system extent, either in LRT system itself, or in other competing modes. Take for example, the sharp fall in San Diego's system between the operating years 17 - 18. This coincided with the expansion by 100 percent of the length of the LRT system. Ridership per directional route mile rises again in year 20 , and may continue to rise as the expanded system becomes established. In general, accounting for route miles produces a ridership plot with a more stable ridership trend as systems expand. The route mile expansion explains a significant share of the growth in ridership. In aggregate, ridership increased by 110 percent whereas route miles increased by 100 percent between the $3^{\text {rd }}$ year after system start-up and the most recent year. Thus, ridership increases were able to slightly outpace line mileage expansion.

There are two possibly contradictory phenomenon of interest in system expansion. Presumably, the expansion of the system allows greater accessibility, which should increase the probability of users in proximity to the system choosing it more as a larger share of their total travel needs would now be accessible via the system. This presumes the expansion offers a more convenient or faster alternative than the preexisting prospect of a possible combination of LRT/bus trip. Also, with more stations, a larger market should be within walking distance for access or egress from the system. On the other hand, an urban area typically will place its initial segment in the strongest market location, often the best transit corridor serving the central business district. The second segment opened would presumably be in the second best location; thus, excluding the prospect of synergistic effects, one might expect the overall system performance (ridership per route mile) to decline with system expansion. One might make similar arguments regarding new start geographic expansion by presuming LRT investments occur in the cities with the strongest markets and, over time, systems are being added in more modest markets. That assumption would presume resource allocation decisions are made from a national optimizing perspective rather than through complex local, state, and national political processes.

Interpretation of Figure 7 also has to include recognition that a host of other factors influence ridership trends, including the strength of the economy, land use/development trends in the 
vicinity of the system, the condition of the competing auto system (particularly the prospect that parallel major facilities are undergoing changes), fare levels, network effects, and service levels among others. In addition, as the system ages, one might expect that the physical condition and perhaps the system reliability may not be up to the same levels as in the early years of operation.

Ridership levels also may be influenced by the extent to which the LRT system is integrated in and supported by the bus system serving the community. In general, the trends in Figure 7 suggest that the levels of use per route mile in subsequent years are remaining at or above the initial levels. Thus, one might surmise that, for the existing LRT cities, there were additional corridors or extensions that offered comparable LRT market opportunity beyond the initial segment. Given that most systems are located in urban areas with several hundred miles of freeways and hundreds or thousands of miles of major arterials, it is not surprising that the modest extensions that are affordable for various cities offer equally promising performance.

In Figure 7, it should also be noted that there is a significant variation in the absolute performance between the various systems.

Table 3 presents data showing directional route mileage changes for a selection of LRT systems and the corresponding changes in ridership. Of the 9 new start LRT systems presented in Table 3, 19 individual instances of directional route mile changes (expansions) took place after operational year 3 , (years 1 - 2 and 2 - 3 are not considered). The LRT system operating in San Diego had the highest number of system expansions (6). The most common operational period for route mile expansion, according to the data, was during operational years $6-7$. This period dovetails with the previous argument that initial ridership maturity may be achieved after operational year 4 (i.e. years 5, 6, 7 etc). 
TABLE 3 - Percentage Change in Directional Route Mileage and Corresponding Change in Ridership from initial segment to 2001

\begin{tabular}{|l|c|c|c|c|}
\hline System & $\begin{array}{c}\text { Year of first } \\
\text { DRM change* }\end{array}$ & $\begin{array}{c}\text { Period of } \\
\text { analysis }\end{array}$ & $\begin{array}{c}\text { Directional mile } \\
\text { change (\%) }\end{array}$ & $\begin{array}{c}\text { Ridership } \\
\text { change (\%) }\end{array}$ \\
\hline St. Louis & $2000-2001$ & $1999-2001$ & 102.35 & -4.62 \\
\hline Dallas & $2000-2001$ & $1999-2001$ & 15.44 & 1.98 \\
\hline Los Angeles & $1995-1996$ & $1994-2001$ & 90.74 & 158.34 \\
\hline Baltimore & $1997-1998$ & $1996-2001$ & 32.11 & -47.82 \\
\hline Denver & $1999-2000$ & $1998-2001$ & 164.15 & 88.91 \\
\hline Sacramento & $1989-1990$ & $1988-2001$ & 10.90 & 140.63 \\
\hline San Diego & $1984-1985$ & $1983-2001$ & 503.75 & 368.19 \\
\hline San Jose & $1990-1991$ & $1989-2001$ & 235.63 & 148.57 \\
\hline Portland & $1997-1998$ & $1996-2001$ & 114.90 & \\
\hline
\end{tabular}

*Note: 1. Year of service introduction = Operational Year 1 (see Table 2)

2. Part-year operations, novelty attraction, aggressive marketing efforts and other ridership initiatives in the introductory years of a new LRT service may produce inflated first and second year ridership levels. Thus, expansion in years $1-2$, or $2-3$ have been omitted.

Source: National Transit Data

Figure 8 graphically presents the data in Table 3. A cursory observation of Figure 8 indicates a modest relationship between the percentage change in directional route miles and ridership, (i.e., expanding the route miles in a LRT system by $X$ percent will not necessarily result in a corresponding change in ridership by $\mathrm{X}$ percent). A regression analysis of the relationship between system expansion and ridership (using data in Table 3 ) results in a low $R^{2}$ value (0.26), confirming the weak relationship. 


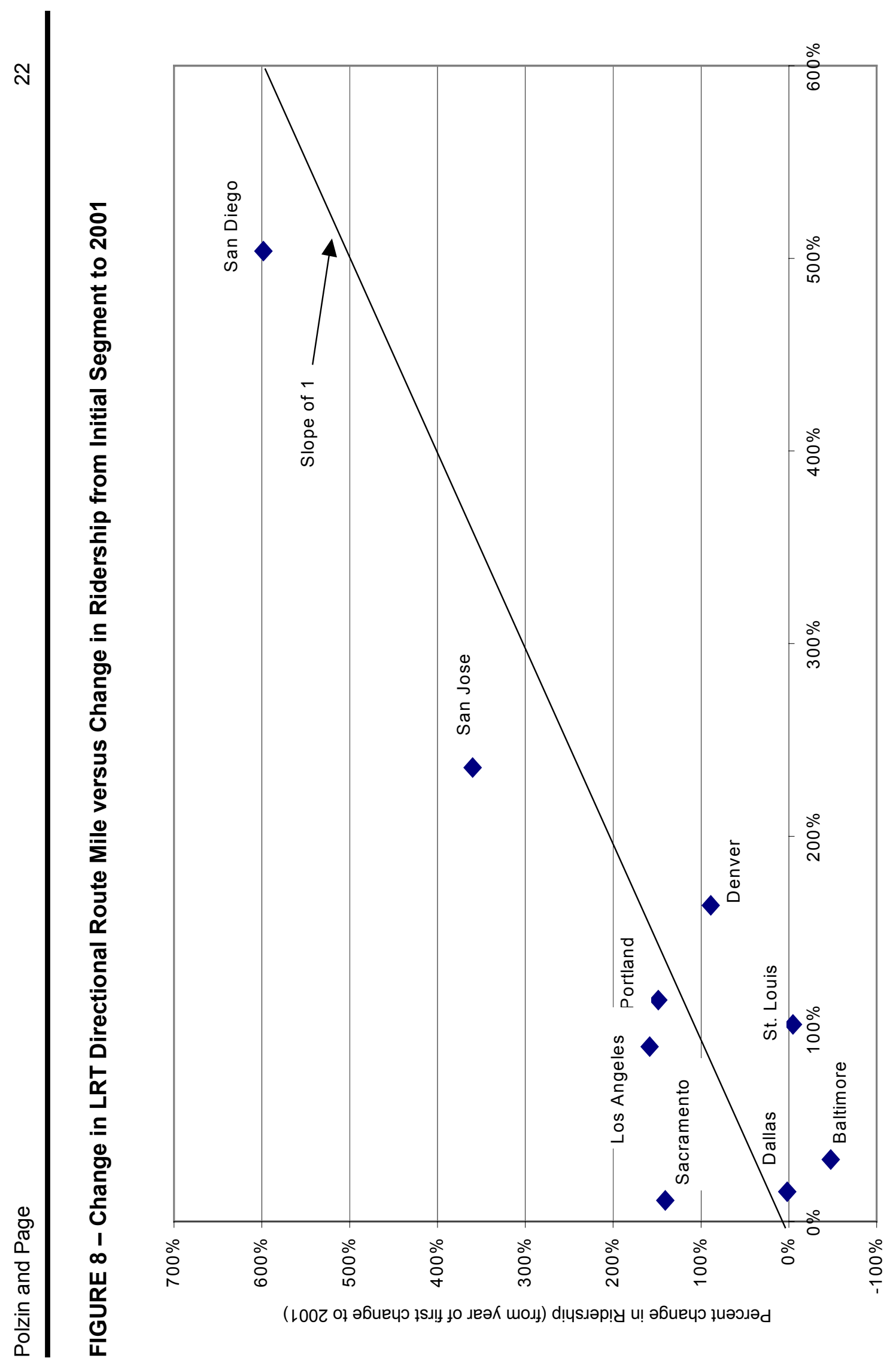

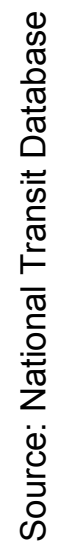


Other data, such as elasticities for transit service supply, suggests that marginal increases in service will result in proportionately lower average productivity. The elasticity for transit service expansion has historically been less than 1 with, for example, a 100 percent increase in service producing perhaps a 65 percent increase in ridership (TCRP, 2000). Of the five new start systems that had route mile expansions of 100 percent or more (San Diego, St. Louis, Portland, San Jose and Denver), Portland, San Jose, and San Diego had corresponding ridership increases greater than their respective changes in directional route miles.

Figure 9 illustrates annual average trip length of new start LRT riders. The extent of urban sprawl and the penetration of the transit system into the suburban areas may result in long trip lengths. The LRT systems operating in the Californian cities of Los Angeles and San Diego may be evidence of this. These systems, in most years of their operation, have consistently experienced high trip lengths when compared to other new start LRT systems analyzed. In making this assessment, one should to exclude trip lengths in year one, as the novelty aspects of system use may still be in force (note for example year 1 trip lengths in Salt Lake City and Baltimore). Low average trip lengths may be due to LRT systems of short system length or those that serve dense urban areas with a correspondingly high density of stations. Examples of the latter are in Newark and Baltimore, which have 1 station per $3 / 4$ and 1 mile, respectively. It is intriguing that there was not greater evidence of increasing trip length over time as systems expand.

Figure 10 graphically presents ridership per 1000 population in a selection of cities. LRT systems operating in the cities of Portland and San Diego stand out due to their consistently high levels of ridership per 1000 population. In the case of Portland, high ridership levels per 1000 population are due to the city's widely acknowledged transit-friendly land use development. Along with transit-friendly development policies, private corporations can also encourage transit ridership by providing incentives in the form of annual passes. Intel Corporation in Portland has offered its employees an annual travel pass for the Tri-Met system.

Figure 11 graphically presents new start LRT ridership as a percentage of overall systemwide ridership. These data suggest that, while LRT has grown to be a significant share of travel in several markets, the public transportation system for LRT cities continues to be reliant on multiple public transit modes, most notably bus based services. 


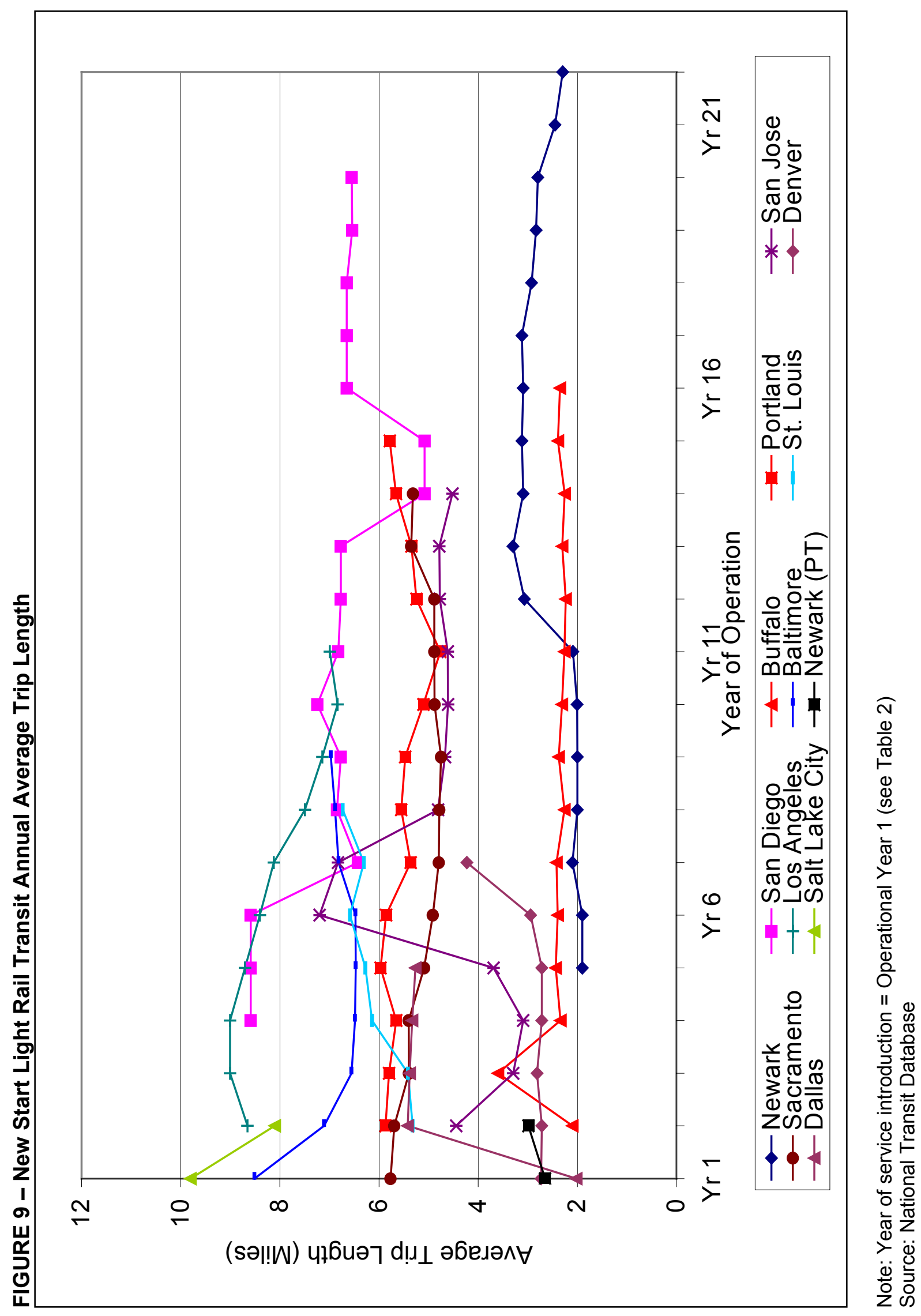




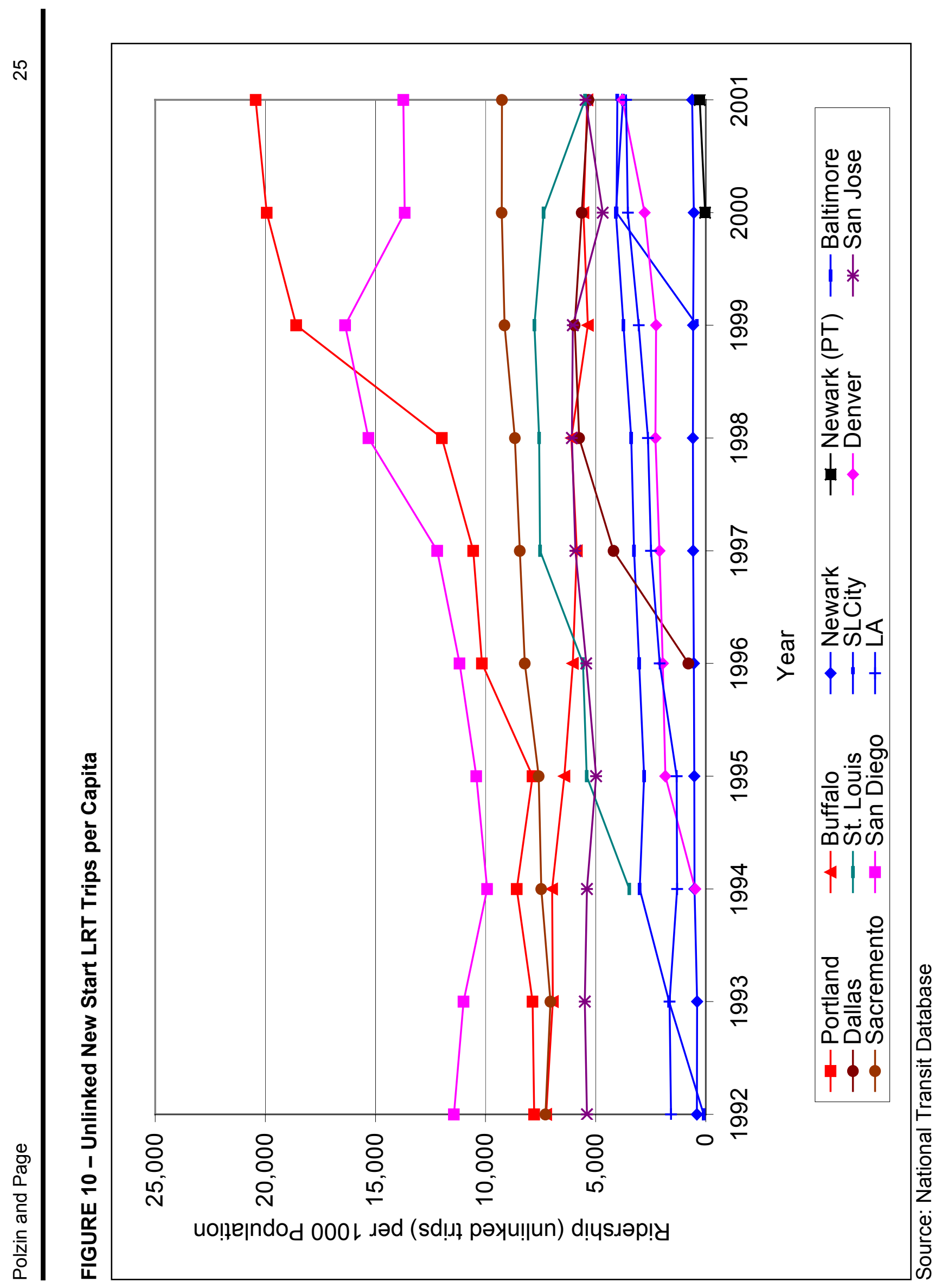




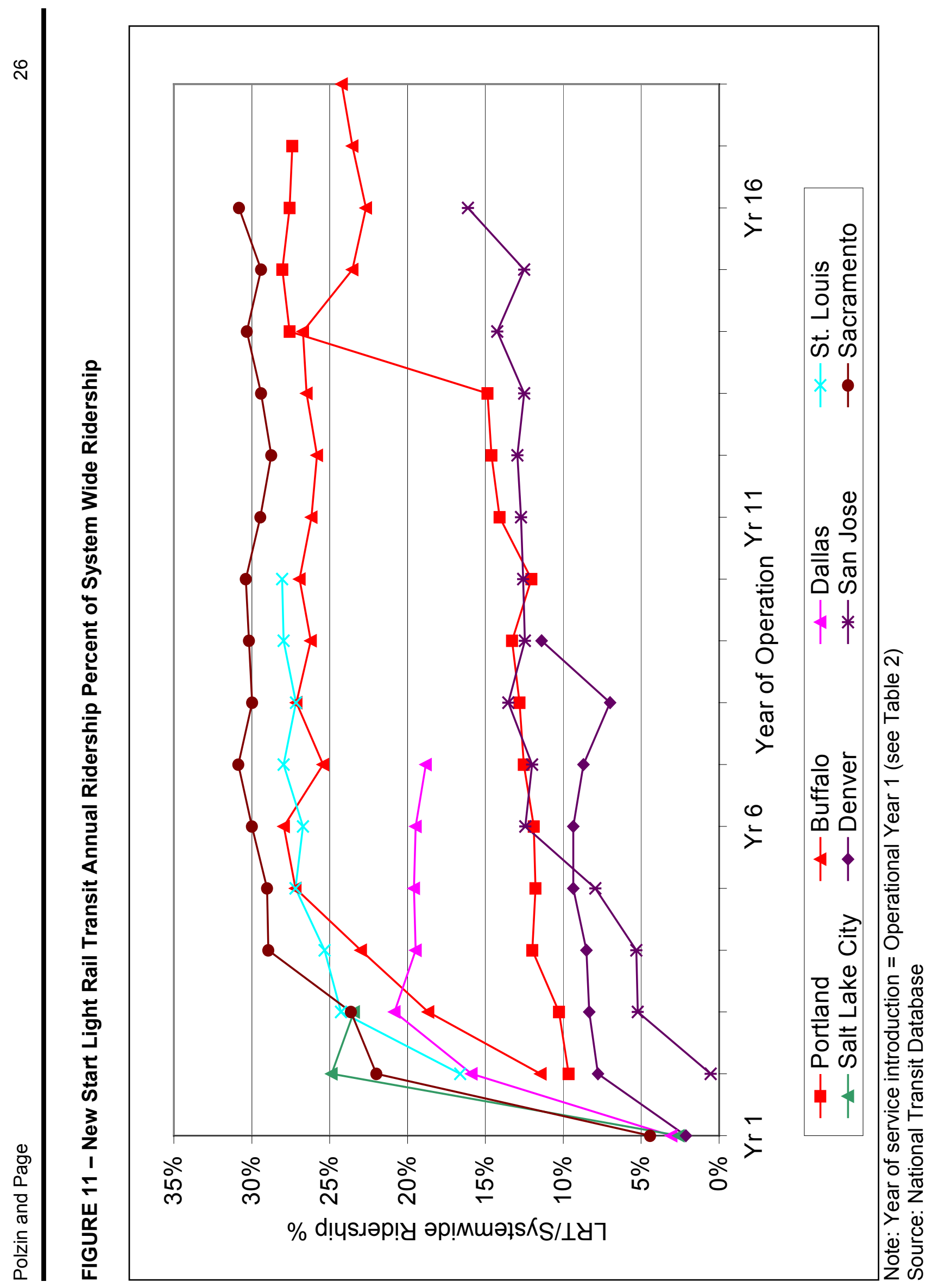


Figure 12 shows the relationship between passenger miles served per directional route mile. This comparison is partially to determine if system expansion provided benefits in terms of more passenger miles of service (not just trips), as this might be expected in cases where system expansion consists of line extensions. This situation might result in cases where a shorter initial line has substantial ridership boarding at a terminal station from distant points accessing the stations via either bus or park-and-ride modes such that the extension might enable a larger share of the individual's total trip to be on the rail segment but not necessarily increase the number of trips. This should show up as an increase in the number of passenger miles per route mile.

Figure 12 also indicates that, for the majority of new start LRT systems, passenger miles per directional route mile increased during the early years of service operation. This result supports the hypothesis made in the previous paragraph, where trip lengths may increase independently of the number of trips. Despite these early year increases, sharp, positive changes in directional route miles after the initial year often result in corresponding sharp falls in passenger service miles per directional route mile. Note, for example, the sharp fall during operational years 17 - 18 in passenger service miles per directional route mile for San Diego; this corresponded to a 100 percent increase in directional route miles (see Table 3). Nevertheless, the LRT system in Portland seems to be the exception where positive changes in directional route miles have not resulted in correspondingly steep negative changes in passenger miles per directional route mile.

Figure 13 shows the relationship between passenger miles served per passenger car revenue mile of service. Passenger miles traveled per revenue mile of service is the best single measure of transportation productivity of a transit investment.

As indicated in Figure 13, a total of 4 new start LRT systems have achieved more than 30 passenger miles for every vehicle revenue mile traveled. Again, 3 of these systems, Los Angeles, Portland, and San Diego, are located on the West Coast; the fourth system is in St. Louis. While these load factors are a modest percent of available places in comparison to airline load factors, they are not dissimilar to autos where the average occupancy is approximately 1.6 compared to a nominal average capacity of 4-5 persons. Maintaining high occupancies in light of directional and temporal fluctuations in demand is an important challenge for LRT systems. In absolute terms, the productivity levels are modest in terms of the typical LRT vehicle capacity, and the trends indicate relatively stable productivity trends for most 


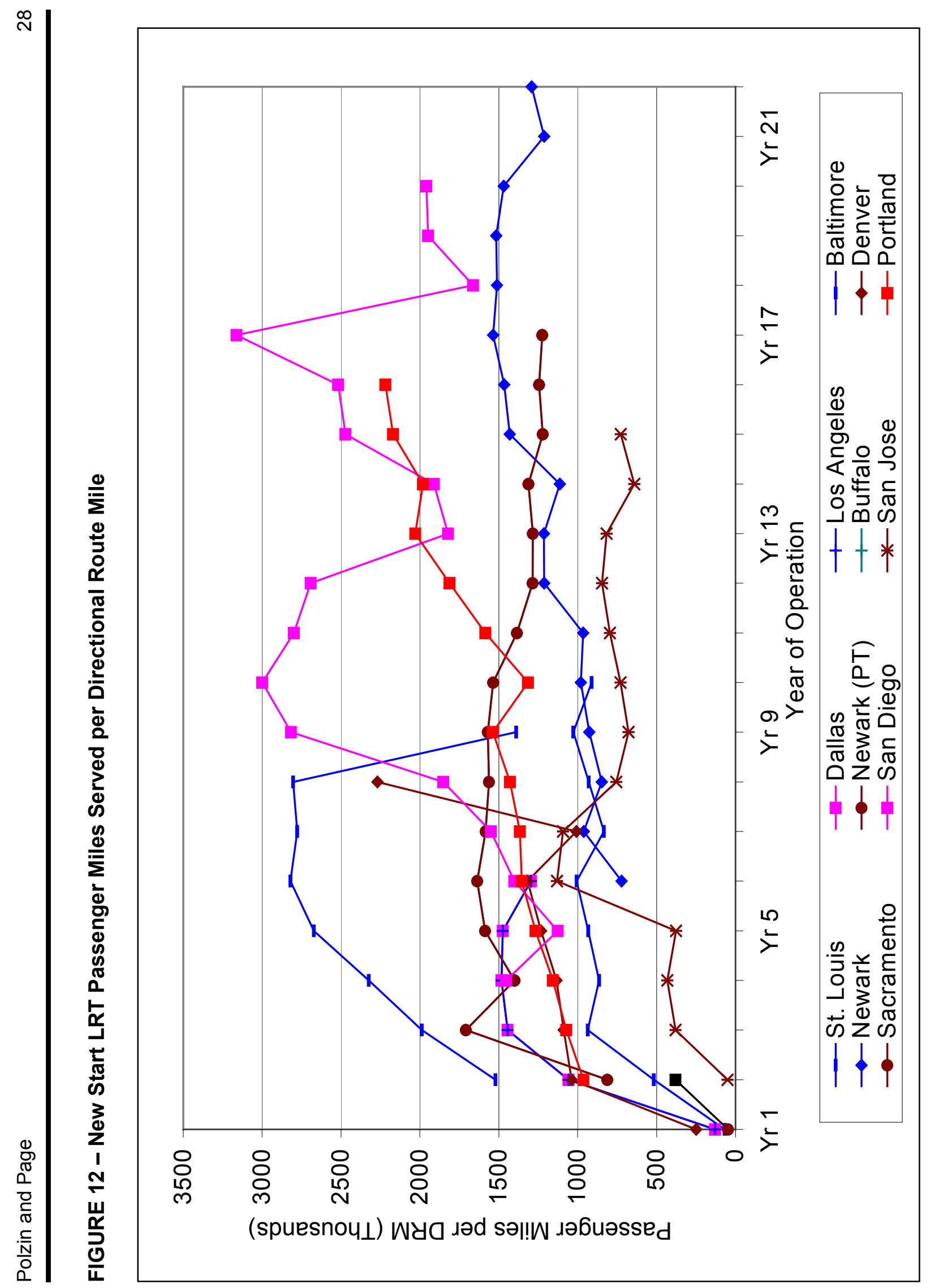

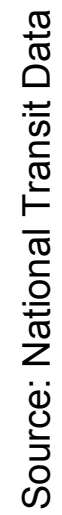




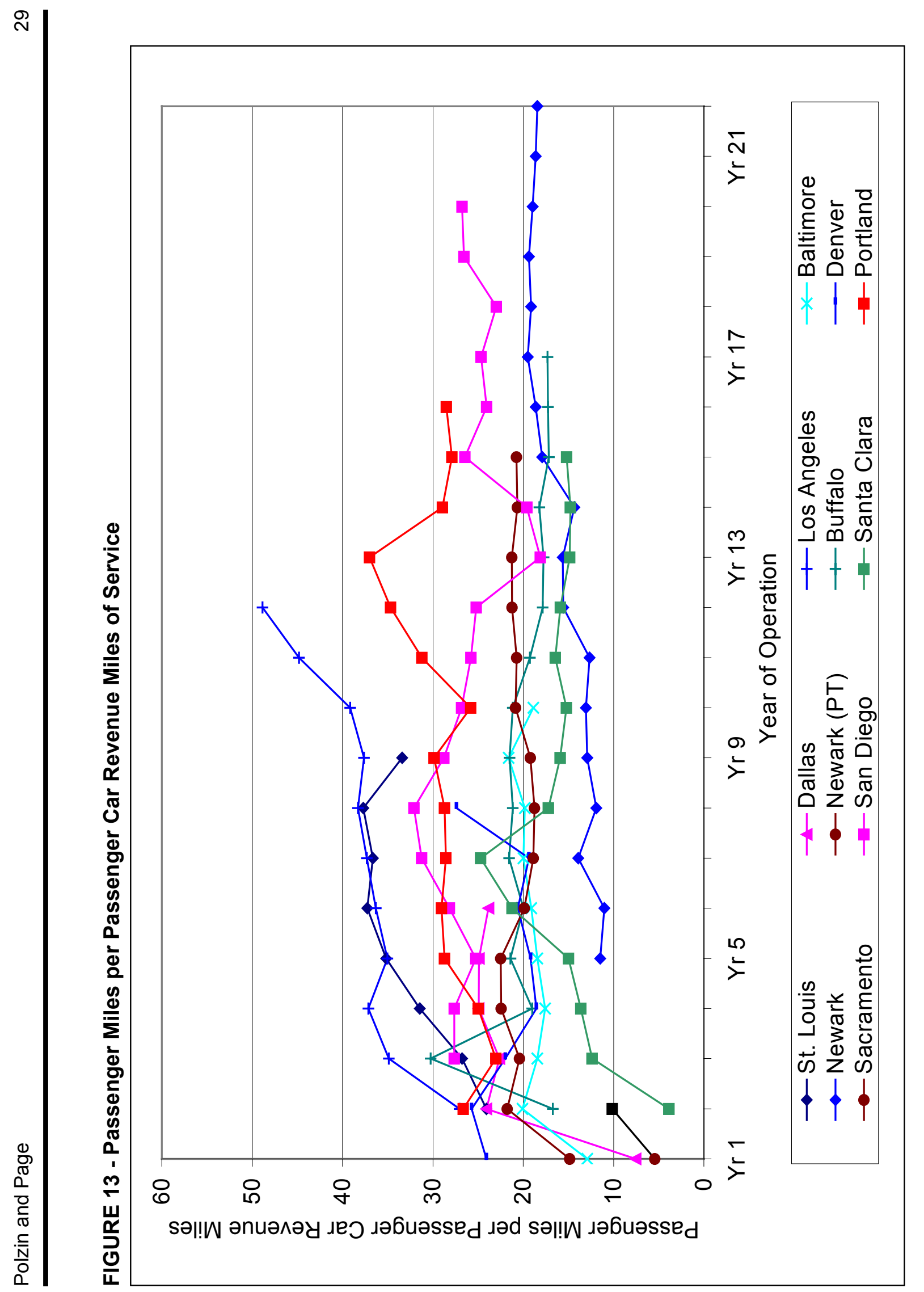

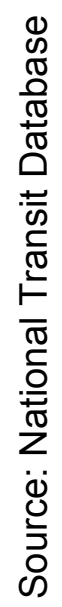


systems. In an era of scarce resources, it would be advantageous if the LRT systems were able to show improved productivity over time to evidence both careful management and traveler and land use response to the presence of systems.

\section{CONCLUSIONS}

Reviews of NTD data indicate that ridership trends for new start LRT projects matured relatively quickly, with subsequent growth driven by system extent and service levels. The initial rapid maturation is no doubt partially attributable to the high profile light rail lines receive when they are under development and implemented. Unlike bus services, where it may take a while for the public to understand where they serve, the physical presence of the LRT system, particularly when it is new and unique in a community, makes it easy to understand. As most systems start with a single line and at best have a very simple network of lines, the general public can quickly understand the service areas for LRT, whereas, the more complicated bus system is more difficult to understand. Thus, bus service planning often presumes routes require up to 2 - 4 years to mature.

Beyond an initial maturation that might be associated with customer awareness of the services, one would also expect to see steady ridership growth related to both a relocation of the population that had an interest in LRT to locations near the system, and growth of population and activities near the stations as land use started to respond to the presence of rail. These trends would be longer-term trends and more difficult to discern, particularly if other factors such as changing economic and demographic conditions, changes in service cost or quality, or other factors such as growing auto availability, come into play.

The route coverage elasticities presented in Figure 7 suggest that system expansion, shown in terms of route miles, is generally as productive as the initial line investment. This is perhaps a result of a combination of factors from the natural growth of population and ridership over time offsetting any tendency for subsequent lines to be built in successively less promising locations. There is no compelling evidence that the synergy of having a larger rail system offsets the disadvantages of what one might assume is implementation in successively less promising corridors. This may be partially explained by the fact that the existing bus services have already captured the synergistic effects of more comprehensive service coverage. More 
detailed context-specific analysis would be required to develop a richer understanding of these phenomena

The review of data also provided some additional observations that may be of use to those involved in planning new systems. It is particularly interesting to note that the LRT systems, even the more mature systems, are a modest share of the urban area's total transit service, with the most successful systems providing approximately 30 percent of total regional transit trips. This situation, as well as the data in Figure 4, indicate that, while the LRT investment may be very important to a community, the current history of LRT implementation has not resulted in dramatic increases in the transportation role that public transit plays in their respective communities. In light of the relatively modest extent of a system that any single urban area can afford to implement in a decade, one would not expect 10 to 30 miles of rail line to dramatically impact overall mobility in an area that most probably has thousands of miles of roadways and hundreds of miles of freeways.

LRT systems appear to mature quite quickly initially, and then show modest increases in ridership unless expanded. The expansions can produce larger increases in ridership, with these increases generally enabling proportional growth of ridership. Finally, Figure 13 indicates that LRT systems have not generally been able to show steady growth in productivity over time. This can be attributed to a variety of factors, including the prospect that the service supply is appropriately managed from the beginning, to the reality that many mode choice considerations such as auto availability and cost, and overall transit system service supply, may be impacting productivity trends. Again, closer context-specific analysis would be required to more clearly analyze this issue. While LRT is playing an important role in expanding transit use, even LRT system development has not made transit ridership expansion easy.

\section{REFERENCES}

American Public Transportation Association, 2002 Public Transportation Fact Book, American Public Transportation Association, Washington DC, 2002.

Center for Transportation Excellence, "Transit Profile: The Portland Area MAX Light Rail System," http://www.cfte.org/images/success portland.pdf 
Federal Transit Administration, National Transit Database 1984 - 2001.

http://www.ntdprogram.com/NTD/ntdhome.nsf/?Open

Gray BH (editor), "Urban Public Transportation Glossary”, Transportation Research Board, Washington DC, 1989.

Polzin S, "Transit Mode Share Trends: What Do the Data Say?" Presentation at the $82^{\text {nd }}$ Meeting of the Transportation Research Board, Washington DC, 2003.

Pucher J, "Renaissance of Public Transport in the United States?" Transportation

Quarterly, Vol. 56. No. 1 Winter 2002 (33-49) ENO Transportation Foundation Inc., Washington DC.

Transit Cooperative Research Program, Traveler Response to Transportation System Changes - Interim Handbook, Washington DC, March 2000. http://gulliver.trb.org/publications/tcrp/tcrp webdoc 12.pdf

Transportation Research Board, "This is Light Rail Transit (electronic document)", Washington DC. http://www.apta.com/INFO/ONLINE/Light rail bro.pdf

\section{Acknowledgements}

The authors wish to thank, Terry Bronson of APTA and David Beal of Metro St. Louis for the provision of statistical data. 
Appendix A

National Transit Database 


\section{NTD Historical Overview}

The National Transit Database (NTD) is the Federal Transit Administration's (FTA) primary national database for statistics on the transit industry. The origins of the NTD can be traced back to Project FARE (Financial Account and Report Elements) in 1972. The first annual NTD report was published in May 1981, representing data for fiscal year ending 1979.

The legislative requirement for the NTD is contained in Title 49 United States Congress 5335(a). The overall goal of NTD is to, 'help any level of government make a public sector investment decision' [with respect to transit]. The NTD repository is used in the following ways:

- $\quad$ Guide public investment decisions of Congress, FTA, and other federal, state, and local governments;

- $\quad$ Apportion FTA funding among urbanized areas; and

- $\quad$ Guide policy development to assist in establishing national priorities and to shape public planning and strategic decision making efforts.

Currently, over 600 transit agencies operating in more than 400 urbanized areas, submit data to the NTD. Of the 19 LRT systems operating (excluding heritage trolley systems) in the USA during 2001, all of these systems submitted data to the NTD.

\section{Transit Agency Data Submission}

The criteria for data submission is that all transit authorities receiving (or benefiting from) Urbanized Area Formula Program (UAFP) grants are mandated to submit annual data. In addition, operators of purchased transportation services that provide mass transportation services under contracts to recipients or beneficiaries of UAFP grants must also submit data to the public transit agency for inclusion in their submission to the NTD. There two general exceptions which relieve transit agencies of data submission, this is where: (i) the agency has nine or fewer vehicles in annual maximum service that operate non-fixed guideway systems, and (ii) private conventional/subscription bus operators that are not under contact to an UAFP grant recipient or beneficiary (though the latter group may voluntarily submit data).

\section{Data submission categories}

Data submissions of transit agencies (which submit data to the FTA) are grouped according to 15 overall themes. These categories and a brief description of each are presented in Table A1. 
TABLE A1: NTD categories

\begin{tabular}{|c|c|c|c|}
\hline $\begin{array}{l}\text { NTD } \\
\text { Table \# }\end{array}$ & Category & Description & $\begin{array}{l}\text { Report Table \#l } \\
\text { Figure \# }\end{array}$ \\
\hline 001 & $\begin{array}{l}\text { Transit agency identification } \\
\text { form }\end{array}$ & Contact information & Figure 10 \\
\hline 002 & Contractual ridership form & $\begin{array}{l}\text { Contractual details of service } \\
\text { provider }\end{array}$ & \\
\hline 103 & Capital funding form & Capital funding source details & \\
\hline $\begin{array}{l}\text { 203-1 } \\
\text { and } 2\end{array}$ & Operating Funding Forms & Operating funding source details & \\
\hline 300 & $\begin{array}{l}\text { Operating expenses summary } \\
\text { form }\end{array}$ & Operating expenses breakdown & \\
\hline 301 & Operating expenses form & Operating expenses breakdown & \\
\hline 321 & Operator's wages form & Wages paid & \\
\hline 331 & Fringe benefits form & Fringe benefits paid & \\
\hline 402 & $\begin{array}{l}\text { Revenue, energy and } \\
\text { maintenance form }\end{array}$ & $\begin{array}{l}\text { Vehicle breakdown, } \\
\text { maintenance and energy } \\
\text { consumption details }\end{array}$ & \\
\hline 403 & Transit way mileage form & System mileage information & $\begin{array}{l}\text { Tables } 1 \& 3 \\
\text { Figures } 5,6,7,8 \\
\& 12\end{array}$ \\
\hline 404 & $\begin{array}{l}\text { Transit agency employee } \\
\text { form }\end{array}$ & Labor statistics & \\
\hline $\begin{array}{l}\text { 405-1 } \\
\text { and } 2\end{array}$ & $\begin{array}{l}\text { Transit safety and security } \\
\text { forms }\end{array}$ & Transit accidents and incidents & \\
\hline 406 & Transit agency service form & Service provided and consumed & $\begin{array}{l}\text { Tables } 2 \& 3 \\
\text { Figures } 1,2,3 \\
4,7,8,9,10 \\
11,12 \& 13\end{array}$ \\
\hline 408 & $\begin{array}{l}\text { Revenue vehicle inventory } \\
\text { form }\end{array}$ & Vehicle fleet information & \\
\hline 901 & $\begin{array}{l}\text { Urbanized Area Formula } \\
\text { statistics form }\end{array}$ & $\begin{array}{l}\text { Summary information of transit } \\
\text { agencies serving urbanized } \\
\text { areas }>200,000 \text { population }\end{array}$ & \\
\hline
\end{tabular}


Table A1 also indicates which of the data in each category was used to derive information contained in the graphics and tables in this report. It can be seen that NTD data from categories 403 and 406 provided the majority of data analyzed and presented in this report.

\section{Data Analysis using NTD}

In the early days of NTD, results were published in hard form. Recently, NTD is available in electronic format, which can either be directly downloaded from the internet or accessed from a CD-ROM. Analysis of NTD in respect of this report was enabled by accessing the Integrated National Transit Database Analysis System module of the Florida Transit Information System. This is a CD-ROM of NTD produced by the Florida International University (Miami). The CDROM allowed analysis by way of queries on NTD, producing results in a variety of formats, e.g. tables, graphics or MS Excel compatible spreadsheets.

In some cases in order to facilitate comparative data analysis, NTD was standardized across systems through focusing on the number of years of service rather than by the actual year of service for each system, respectively. For example, two LRT systems commencing services in the years 1985 and 1995 respectively, would naturally result in two separate points on a year based time line; nevertheless, both would be placed at year 1 , if the time line were according to years of service. Through his method a more direct comparison and analysis between each individual transit system data was achieved.

\section{References}

Review of the National Transit Database http://www.fta.dot.gov/library/ntd/1.\%20Introduction\%20v12.htm

2002 National Transit Database Reporting Manual, 2002 http://www.ntdprogram.com/NTD/ReprtMan.nsf/Web/PDFFiles2002/\$File/Introduction20 02.pdf 